\title{
Technology in Music Education: A Survey of Computer Usage in Teaching Music in Selected Colleges of Education in Ghana
}

\author{
*Eddison Foster Mawusi \\ Mphil. E.P. College of Education. Bimbila, Ghana W/A \\ Joseph Nkyi- Asamoah \\ Med/Mphil. Offinso College of Education, Offinso-Ashanti Ghana W/A \\ Klutse Eric Kwadwo \\ Mphil. E. P. College of Education, Bimbila, Ghana W/A
}

\begin{abstract}
The study sought to find out the role of computer technology in music education in Colleges of Education in the Volta Region of Ghana. It aimed at surveying the use of computer technology for teaching music and exploring the instructional prospects for computer technology usage in music in Colleges of Education. The study employed Rogers' Diffusion Innovation theory and descriptive survey research method. Data was collected from the respondents using questionnaire, interview, and observation. The study revealed that even though about $90 \%$ of the music tutors have good academic qualification and over five years teaching experience, lack of competence in handling computer technology in teaching music among some music tutors and incoherent ICT initiatives hindered proper application of computer technology in the field of music education. It is however envisaged that increasing access and coherent computer technology initiatives will be paramount for the teaching of music in the Colleges of Education.
\end{abstract}

Keywords: COE

DOI: $10.7176 / \mathrm{JEP} / 11-3-15$

Publication date: January $31^{\text {st }} 2020$

$\begin{array}{ll}\text { GETF - } & \text { Ghana Education Trust Fund } \\ \text { FCUBE - } & \text { Free Compulsory Universal Basic Education } \\ \text { ICT - } & \text { Information and Communication Technology } \\ \text { ICTS - } & \text { Information and Communication Technologies } \\ \text { ICT4AD- } & \text { Information and Communication Technology for Accelerated Development } \\ \text { ICT4E - } & \text { Information and Communication Technology for Education } \\ \text { ICTEPU - } & \text { Information and Communication Technology in Education Programmes Unit } \\ \text { IT - } & \text { Information Technology } \\ \text { MOESS - } & \text { Ministry of Education, Science and Sports } \\ \text { NEPAD - } & \text { The New Partnership for Africa Development } \\ \text { GIFEC - } & \text { Ghana Investment Fund for Electronic Communications }\end{array}$

Background of the Study

The application of Information and Communication Technology (ICT) in sectors of human endeavour including education seems to be a paradigm shift from the normal traditional concepts of operations towards a more refined and transformational processes with significant enthusiasm. Social, political, religious, economic, and technological changes of the past decades make education and training for all and sundry more crucial than ever. However, educational systems, to different degrees worldwide, are struggling to afford educational opportunities for all, to provide their human resource with the necessary knowledge and skills for capacity building in evolving economies and sophisticated living environments, and to prepare citizens for lifelong learning (Soloway \& Pryor, 1996). In order to meet these challenges, many Sub-Saharan African countries have to focus concurrently on access enabling environments, improving internal efficiency, promoting the quality of teaching and learning, and improving system management.

The application of computer technology in the field of education has gained and rapidly continues gaining ground in various institutions around the globe. With the ever increasing changes in the global economy, Africa for that matter Ghana's educational sector has been challenged to enhance its instructional technology in order to participate effectively in the global technological age (Reeves \& Jonassen, 1996). Developing nations like Ghana also perceive integration of ICT in education as an engine for promoting socioeconomic, political, and sustainable development. This perception underpins many major attempts to improve upon the educational sector to meet the demand and human resource requirement of the country (Mangesi, 2007). The quest for educational improvement as stated by Mangesi triggered the enactments of several educational reforms and initiatives. The Ghana Education 
Trust Fund (GET Fund Act, 2000) was established to provide educational infrastructure for schools, colleges and universities. The New Educational Reform (2007) incorporated the study of ICT in Basic and Senior High School and establishment of Ghana Investment Fund for Electronic Communication with the vision of bridging the digital divide between the served and unserved/underserved communities in Ghana.

According to UNESCO (2008), all over the world, educators, policy makers, policy implementers and researchers have collectively agreed on the potential of ICT to have a significant and positive effect on education (http://en.unesco.org/themes/ict-education). The Government of Ghana's efforts in recognizing the benefits of embracing ICT and incorporating it in the latest educational reforms which took effect from the 2007/2008 academic year, has been done to enhance the efficiency and effectiveness of the teaching and learning process. It also aimed at equipping the nation's human resource capacity base with the requisite ICT skills and knowledge to meet the challenges of the ever changing world that await them outside the classroom (Ghana ICT in Education Policy, 2015). Education policymakers in Ghana have applauded the introduction of Information and Communication Technology (ICT) in sectors of education as a step towards knowledge production and communication, and information sharing among students and teachers in the school system (Ghana ICT in Education Policy, 2015. pp. 12). As a result of the educational reforms currently underway ICT has been introduced as a subject of study and computer technology as a tool for teaching and learning. This requires a huge capital investment. The Colleges of Education have been entrusted with oversight and implementation responsibility towards insuring effective integration of ICTs and training of teachers for basic school in Ghana.

The major concern here is how much computer technology has been integrated into the teaching of music in the Colleges of Education. How is computer technology used in the teaching of music towards effective music teacher training; these and many more questions not answered propelled the choice of the sector that trains the human resource for our basic schools and a particular area of music education. As a matter of necessity, regarding technology integration in education in Ghana, the question still exists as to what role technology plays in transmission of knowledge and lesson delivery. In an attempt to answer the question, we turn to learn from similar past experiences, improve service delivery in particular, plan and allocate resources to teaching and learning, and finally demonstrate results. It has been over ten (10) years of introduction of computers and other ICTs in Colleges of Education in Ghana (Ghana ICT for Accelerated Development (ICT4AD) Policy, 2003, pp. 38). The purpose for the integration process was to enhance teaching and learning and to help diffuse new pedagogies across learning experiences in the educational system. Surprisingly, many tutors and students have perceived the use of ICTs as means to an end but not as a tool for teaching, learning and development.

Seemingly, for the past eleven years of ICT becoming a subject of study and a tool for teaching and learning, there has not been any research purposively directed to assess the usage of technology in terms of computer in the teaching of music in Colleges of Education in Ghana. Interestingly, the Colleges of Education are responsible for the training of music educators for basic schools. Again, apparently there are scarce or no documents in relation to the use of computer technology in teaching music in the teacher training institutions in Ghana. Some music tutors in Colleges of Education are enthusiastic about using technological tools like computers in their lesson delivery. The same way some principals are interested in improving teaching of music in their colleges. The apparent reluctance of older teachers to use technology is understandable to some degree. This might explain why technology, when used by such teachers, is often utilized in a past model of teaching and learning. The question must be asked how open minded and sensitive are college music tutors in terms of computer usage to preparing students for knowledge and skills that can equip them for both the present and the future. The researcher was motivated by the public sector led ICT initiatives in Colleges of education and embarked to survey the use of computer technology in teaching music.

\section{Statement of the Problem}

Marcellino (1996) contends that music technology has brought challenges to the traditional concepts of art, and the very elements of music making. Technology evolves so does music and the use of technology in music education. The draft copy of ICTE Policy revealed that in a study carried out to review and assess the ICT in Education Initiatives in Ghana, twenty initiatives were selected and their impact assessed to see what lessons could be learnt. Several positive achievements were noted: initiatives contribution to a wider number of students and teachers acquiring ICT skills and developing strong interests in ICT and Science, schools involving in the initiatives were motivated to expand the project and / or acquire more ICT equipment; a number of private-public partners, including Parent Teachers Associations (PTAs) and civil society collaborated in the efforts and lessons learnt from initiatives provided good examples for other schools to introduce their own ICT programmes. The researcher conducted a pilot survey of the use of computer technology in teaching music in Peki College of Education. The findings revealed that even though there were much evidences of the use of computer in education in the colleges, very little is seen about computer usage in teaching music. During this pilot study, unavailability of similar local research to provide enough information on the use of computer technology specifically in music education was identified. The pilot survey findings also unfolded scarcity of relevant literature in the use of 
computer technology in music education in Ghana. The relevance of computers to the field of music education has not received sufficient attention. Music educators and learners alike may not be fully aware of the possibility, let alone effectiveness, of using computer for the dissemination of information and development of skills that facilitate learning in music (Okonkwo, 2008, pp38-39).

Through observations and pilot study, the researcher realized that despite the perceived availability of computers in Colleges of Education in Ghana, there seemed to be little known about their usage in teaching music. In the face of this baseline knowledge, little has been discussed on application of computer technology to improve the traditional approaches and methods of teaching music in College of Education in Ghana. Generally, there is the need for a review or assessment of computer usage in regards to teaching of music in colleges due to its eminent roles played in teaching and knowledge acquisition. Again, much has not been recorded in terms of documentation about the usage of computer technology in teaching music in Colleges of Education. Hence, it is necessary that the attention of key stakeholders in music education be drawn to this phenomenon. This study therefore surveyed the role of technology in music education, and especially the usage of computer in the teaching of music in Colleges of Education in Ghana

\section{Research Objectives}

The objectives set for the study were

i. Determine the accessibility of computer technology to tutors and students of colleges of education in the Volta Region.

ii. Document the instructional prospects for using computer technology in teaching music

\section{Research Questions}

The following research questions were formulated to guide the study:

i) In what ways are computer technology facilities accessible to tutors and students?

ii) What instructional prospects are there for use of computer in music education?

\section{Significance of the Study}

The benefits that computer technologies bring are unhidden fact. This study sought to provide useful lesson for policy makers on the nature of future ICT usage in teaching of Music and to serve as an assessment for the public sector led ICT initiatives to the central government. Again, the study sought to espouse the awareness of the importance of using appropriate computer technology facilities in teaching other subjects and to provide some base knowledge for future research in this area. The researcher thereby hopes that this thesis will provide the basis for anyone who may wish to research into similar work for any educational institution in Ghana and elsewhere.

\section{Theoretical framework of the Study}

This study primarily was based on the theory propounded by Rogers (1962), known as the Theory of Diffusion Innovation. Diffusion Innovation theory is defined as the process by which an innovation is adopted and gains acceptance by members of a certain community. Rogers (2003) stated that adoption is a decision of "full use of an innovation as the best course of action available" and rejection is a decision "not to adopt an innovation" (p. 177). According to Rogers, there are a number of factors that interplay to influence the diffusion of an innovation. These factors include the innovation itself, how information about the innovation is communicated (communication channel), time, and the nature of the social system (the institution) into which the innovation is being introduced (Rogers, 1962). In view with Rogers, the introduction of new technology must be well explained to users and considering the appropriateness of the technology to the sector that is to use it. The medium of communication becomes paramount for the user institution. The question that remains answered is how much education was done before and during the computer integration in colleges of education in Ghana. How much awareness of computer literacy was created in both students and tutors of colleges of education? In any case, Rogers' assertion is right because it calls for proper assessment and analysis of colleges of education's computer technology needs for effective use of computer technology in education.

\section{a) Innovation:}

Rogers (2003), innovation is an idea, practice, or object that is perceived as new by an individuals or groups or unit of adoption. The perception of an innovation and the rate of adoption are usually determined by the members of the social system based on certain characteristics such as: relative advantage, compatibility, complexity, trialability and observability. Here, Rogers are of the view that the acceptance of any innovation for that matter computer technology into any social setting must be well weighed. The said innovation must be simple to operate, suitable to the environment or the social setting, user friendly and appealing. Again, a critical consideration must be given to the advantage the innovation has over the existing one in use. It is therefore believed that computer technology would play roles that are more cost efficient in the delivery of music lessons over the traditional set standards. 


\section{b) Communication:}

Communication is the process by which participants create and share information with one another in order to reach a mutual understanding (Rogers, 2003). A communication channel according to Rogers is the means by which messages get from one individual to another. Rogers states "source is an individual or an institution that originates a message, a channel is the means by which a message gets from the source to the receiver" (p. 204). Mass media channels are more effective in creating knowledge of innovations, whereas interpersonal channels are more effective in forming and changing attitudes toward a new idea, and thus in influencing the decision to adopt or reject a new idea. Rogers stated "diffusion is a very social process that involves interpersonal communication relationships" (Rogers, 2003, p. 19). Most individuals evaluate an innovation, not on the basis of scientific research by experts, but through the subjective evaluations of near-peers who have adopted the innovation. Rightly said, easy adoption of any technology means practical hands-on by an individual. Better learning experience takes place among peers. For new technology to be well adopted in an institution, individual must have adequate access and frequent interpersonal relationship with the technology and other peers that use the same technology.

\section{c) Time}

Rogers believed that in diffusion of innovation, time involves three things.

i) The innovation-decision process. This is the mental process through which an individual (or other decision making unit) passes from first knowledge of an innovation to forming an attitude toward the innovation, to a decision to adopt or reject, to implementation of the new idea, and to confirmation of this decision. An individual seeks information at various stages in the innovation-decision process in order to decrease uncertainty about an innovation's expected consequences. There are five steps involved namely: 1) Knowledge, 2) Persuasion, 3) Decision, 4) Implementation and 5) Confirmation.

ii) The innovativeness of an individual or other unit of adoption. This involves the degree to which an individual or other unit of adoption is relatively earlier in adopting new ideas than other members of a social system. There are five adopter categories, or classifications of the members of a social system on the basis on their innovativeness: 1) Innovators, 2) Early adopters, 3) Early majority, 4) Late majority and 5) Laggards.

Malachi (2007) in his unpublished thesis stated that the Innovators are those who are interested in technology itself, financially sound, well-educated and risk undertakers. Early adopters may be technically sophisticated and interested in technology for solving professional and academic problems. Early majority are pragmatists and constitute the first part of the mainstream; Late Majority are less comfortable with technology and are the skeptical second half of the mainstream; laggards may never adopt technology and may be antagonistic and critical of its use by others. They are financially less stable, conservative, less educated and fear to undertake risky operations.

iii) The rate of adoption. This is the relative speed with which an innovation is adopted by members of a social system. The rate of adoption is usually measured as the number of members of the system that adopt the innovation in a given time period.

\section{d) Social System}

Rogers (2003) defined social system as "a set of interrelated units engaged in joint problem solving to accomplish a common goal" (p. 23). Since diffusion of innovations takes place in the social system, it is greatly influenced by the social structure of the social system such as norms, opinion leaders, and the degree to which an individual is able to informally influence other individuals' attitudes or overt behavior in a desired way with relative frequency. The members or units of a social system may be individuals, informal groups, organizations, and/or subsystems. The social system constitutes a boundary within which an innovation diffuses and a change agent is an individual who attempts to influence clients' innovation-decisions in a direction that is deemed desirable by a change agency.

This diffusion innovations theory by Rogers, all over the years, is believed to be the most appropriate for investigating the adoption of technology in higher education and educational environments (Medlin, 2001; Parisot, 1995); hence appropriate for this study. This theory was viewed appropriate for the study as it laid a strong case for the adoption of computer technology as a new educational tool and its usage in music education. Technology integration in education in Ghana is quite new process. In Ghana, the policy document for National ICT Programme seeks to inform sector stakeholders as to why ICTs are very important part of our modern society. Again, it looks at the eminent roles teaching of music play in our educational system and life as general for which much attention must be given.

Learning is said to be mediated by tools and signs. These tools are said to be created by the culture of the people in which the environment places greater role. Computer technology as a tool changes the culture. The purpose of the tool is to meet the goals of the participants in the culture and thereby transforming their participation in the culture (Duffy \& Cunningham, 1996).

There are indications that teachers proceed to adopt ICTs in stages and initially focus on their own interaction with the new medium, and as they gradually become comfortable with the technology they start deliberating upon potential learning benefits that would result from the use of the computer. Myhre (1998) concludes that this 
increased familiarity with computers allows teachers to turn their interest to the pedagogical use of technology rather than its operational issues, but also emphasizes that such change processes do not occur rapidly and are not easily achieved. Tutors and students and even policy makers struggle to comprehend working dynamics of this innovation. Many old folks in the educational system reject computers and their capabilities while the young appreciate the device. The world today is viewed as a global village. Ghana as a country benefited from the influx of knowledge about the eminent roles played by technology for that matter computer technology. There is therefore the need to assess how far this new tool (innovation) has been adopted and used within the context of music teaching. It is in this regard that Surry (1997) asserted that increased awareness of diffusion's importance and expanded use of diffusion theories are of potentially great benefit to instructional technology in the field of music education.

\section{Technology as a Teaching Tool}

The computer is an exemplar of mediational means that has aspects of both tool and sign. The computer's role in education has been largely viewed as an instructional tool and for providing a richer and more exciting learning environment (Duffy \& Cunningham, 1996; Jonassen \& Reeves, 1996; Taylor, 1980). However, by focusing on the learner, the role of technology can support new understandings and capabilities, thus, offering a teaching tool to support thinking and application of reason. The traditional view of instructional technologies of instruction as conveyors of information and communicators of knowledge is supplanted with active role the learner plays in learning with technology. Technologies, primarily computers, help build knowledge bases, which will engage the learners more and result in more meaningful and transferable knowledge. Learners function as designers using the technology as tools for analyzing the world, accessing information, interpreting and organizing their personal knowledge, and representing what they know to others.

Duffy \& Cunningham (1996), cognitive tools do not prevent the use of computers to increase productivity for learning. Off-loading repetitive tasks and lower order tasks to cognitive tools frees cognitive resources for deeper thinking and reduces errors. Swain and Pearson (2002) revealed that teachers and students must be educated to use the computer as a productivity tool, as well as a tool for learning, research, networking, collaboration, telecommunications, and problem-solving. Using computers as a productivity tool is one of the basic requirement for teachers to use technology to enhance their productivity and professional practices. Enhancing human capacity of teachers, there is the need to provide extensive teacher professional development for teachers. Such capacity building programmes can be online teacher professional training, face to face training workshops among others. The professional development includes more than training in equipment operation. The new pedagogical models required in the adoption of constructivist and constructionist learning outcomes call for training of teachers in these skills and knowledge base. Gardner (1991), many students do not actually understand or find meaning in what they learn. To some, education becomes nothing more than drill and practice or drill and response to routine tasks without relevance for the materials that students are expected to learn. Gardner stated that Psychologists such as Piaget believed that the learner must be active to be engaged in real learning. Active learning is regarded as the ability to connect new knowledge with prior understanding. Technology integration education therefore provides a better opportunity for both the teacher and the learner to have the firsthand experience for better learning outcomes. In the context of traditional learning, students are passive recipients of knowledge that are inconsistent with the learning situations that occur in real life. Therefore, in order to make students learning relevant to real life experiences, learning environments call for pedagogical change and reformation (Lave, 1988).

\section{Current trends in the development of computer technology and its application in music education}

The technology applies to and describes a wide variety of devices and applications in music and music education. Generally, technology is anything that uses science knowledge to achieve a desired result (http://www.useoftechnology.com/what-is-technology/). Technology has assisted performers and music educators for centuries. The organ, harpsichord, piano, and phonograph are all examples of technologies that were as amazing to those who originally used them as computers are to us today. The trumpet was played without valves throughout the Baroque era. In the Romantic period, the valve was incorporated into the design of the trumpet and this technology revolutionized the instrument. Likewise, the invention of the silicon chip and computer microprocessor in the late twentieth century have had as great of an impact on music and music education (Rudolph, 2004, p. 1). The use of computer technology to support learning has been difficult to document and quantify (Brennan \& Lockridge, 2006), leaving the role of computers in the classroom precarious. In the past decade, a sudden resurgence of interest was markedly observed in the classroom use of technological innovations, along with the increased use of the Internet and other digital technologies (Reiser \& Dick, 2002). Mereku (1999), to be able to achieve competency- or performance-based music teacher preparation targets, prospective teachers must have knowledge about music (i.e. Theory and Literature of Western and African Music); knowledge in music (i.e. Learning and Teaching of both African and Western Musical Instruments and Composition) and knowledge of music education studies (i.e. Philosophy, Psychology, History, Pedagogy, Assessment and Evaluation, and 
Research). Mereku advocated for electronic keyboards that are cost effective instead of acoustic pianos of the past. According to him, there is the need to enhance students' practices by providing individual instrument rooms. In the training of professional music teachers, he is of the view that every music department must set up Music Technology Laboratory for sound engineering, music programming and recording by the help of computers. Departments responsible for the training of music teachers must ward off obsolete instruments and employ electronic experts that are competent and effective for the job. In order to express the need for a turn-around of the music education in Ghana, Mereku said: "It must be reiterated that a good music education programme must take cognisance of the cosmopolitan nature of the new mixed cultural legacy of this country. We need to put into proper perspective our musical heritage - both past and present. Forcing a curricular that is community-oriented will not be doing justice to prospective teachers in their preparation process because that is not the reality on the ground. We will be terribly wrong in this regard if we continue to pursue a cultural revival policy". This assertion by Mereku is a wake-up call to institutions that train music teachers to restructure their training programmes to suit the challenges of using technology in education. The colleges of education for that matter the institution mandated to train music teachers for basic schools must therefore embrace computer technology integration and its' effective for both teaching and learning processes.

The field of Instructional Design and Technology, too, saw the evolution and emergence of alternative approaches. New emphases, like electronic performance support systems, web-based instruction, and knowledge management systems widened its horizon across business and industry, the military, health care and education, worldwide (Reiser, 2002). Initiatives, such as situated learning theory and constructivism presented fresh approaches to bring about reforms in the domains of public education and higher education (Anderson, Reder \& Simon, 1996; Brown, Collins \& Duguid, 1989; Jonassen, 1999; Reiser, 2002). In this study, the most recently invented state-of-the-art devices such as computers, electronic keyboards, CDs, CD-ROMs, and DVDs were considered. Other devices such as the overhead projector, phonograph record player, cassette recorder, and filmstrip projector are no longer considered cutting edge (Rudolph, 2004). In the last two decades many tools have become available to music educators that can significantly enhance student learning. To comprehend the prospect of technology implementation in enhancing the teaching-learning process, the impact of constructivism on classroom practices has been studied by many researchers (e.g., Black \& McClintock, 1995; Richards, 1998; Brush \& Saye, 2000). Other researchers have suggested that constructivist strategies exploit technologies for greatest impact in learning (e.g., Duffy \& Cunningham, 1996). This study therefore looked at some of the strategies espoused by the Constructivists in order to state and explain the prospects of technology adoption and usage in colleges of education in the Volta Region.

A complementary relationship appears to exist between computer technologies and constructivism, the implementation of each one benefiting the other. It is therefore important for music educators to be aware of the full capabilities of these tools that can help students to better perform, create, and understand music. According to Akuno and Digolo (2000), the use of computers in music education has taken upward trend over the past decade and there are significant successes in the development of different computerized application software for use in education and allied fields. According to Malachi (2007), computer software can be categorized into three areas: "cognitive (knowledge-based material), psychomotor (skill and perception-based material) and affective (values and experiential materials). The cognitive content software is by far the largest, dealing with facts, terms, historic information, theoretical analysis, pitch systems, and other information about music. The programmes in this area teach through drill-and-practice, tutorial interaction, game techniques or problem solving. More advanced programmes combine several approaches. Examples of these programmes include Early Music Skills, Music Flash Cards or Keyboard Tutor. The software is colourful, fast moving and randomized for repeated usage. The content covers note reading, scales and music keyboard topography".

Jonassen, Peck and Wilson (1999), technology is referred to the designs and environments that engage learners. The focus of both constructivism and technology are then on the creation of learning environments. Looking at the assertion made by Muro (1996), it revealed that the ideal teaching tools for the music curriculum is the computer therefore needs careful selection of computer software packages for adoption and/or use. Lehman (2001), stated, "the computer revolution in music education won't begin until we rethink what we want education to be. Only then can we clarify our goals and bring them into focus. Only then can we know how to use computer. Only then can we know what we want in educational software. At the very least we must have software that is genuinely interactive and genuinely individualized". The use of computer technology in colleges of education would be useless if the goals and aspirations of college education system are not critical considered. Agreeing with Lehman, critical assessment of college programmes would enable proper selection of computer technology hardware and software for effective and profitable delivery of education.

There are hundreds of ways to misuse computers in education and only a few ways to use them properly. Peters (2000) contends that the use of software designed to teach, tutor and sequence a student's learning has been available in music since the late $1980^{\circ e}$ s. Many of the programmes were drill-and-practice programmes in eartraining and music theory. Software content ranges from note-names, to music history; from composer biographies 
to African instruments. It is noted with much concern that Peters' assertion may only be right in terms of first class nations. There are many other nations within the third world that continue to struggle with access to computer technology. To them, the use of music software is an innovation. Again, even though some individual countries might have experienced the use of music software in one way or the other (usually in the music industry), its integration in education may the latest as in the case of colleges of education in Ghana.

\section{Prospects for computer usage in Music Education in Colleges of education in Ghana}

According to Bauer and McAllister (2003), there are three indicators that contribute to teacher effectiveness namely; teacher knowledge, teacher comfort, and frequency of teacher use. Sevan (2016), "the role of the teacher for that matter music teacher has changed as the traditional education methods, techniques and applications have left its place to the student-centered methods, techniques and applications along with the $21^{\text {st }}$ Century. Teachers are no more sources and share the information but do guide students to access information and manage the process". In this vein, learning is viewed as the construction of meaning rather than as the memorization of facts (Lebow, 1993; Jonassen \& Reeves, 1996). For technology innovation in the classroom, the teacher's attitude is of much concern because it forms the major enabling or disabling environment for technology adoption. Teacher's attitude toward ICT is said to be a key factor not only for enhancing computer technology integration in the classroom but also for avoiding teachers' resistance to computer use (Watson, 1998). The attitudes and beliefs of the teacher affect the way technological innovation is adopted and applied in education. The teachers' attitudes and beliefs also influence what they themselves learn from education and training programs and what didactic practices they make use of in their classrooms (Clark \& Peterson, 1986; Fang, 1996; Pajares, 1992; Zeichner et al, 1987).

Learning approaches using contemporary ICTs provide many opportunities for constructivist learning through their provision and support for resource-based, student centered settings and by enabling learning to be related to context and to practice (Berge, 1998; Barron, 1998). By implication, the efficient utilization of technology and for that matter the integration of computers into the music lessons is of great importance for a meaningful and effective education. This process of computer integration would create more motivated environment that sustains interest and happiness in music lessons and a good platform for permanent learning. This theory backed the study to find out the motivation behind students' choice of music as an elective subject The prospects of computer usage in music education come with some deficiencies that cannot be overlooked in an effective integration process. These deficiencies involve:

a) music teacher's lack of knowledge on the use of computers

b) inappropriateness of the physical conditions of the class environment

c) insufficient number of computers for students

d) lack of software

e) lack computer programs

f) lack of technical assistance

This study addressed the above deficiencies looking at possible suggestions and recommendations to encourage technology use and especially computer technology integration for effective music education in Colleges of Education in Ghana. According to a study conducted by Yamaha Corporation, it was revealed that successful computer technology integration in music education provides the following:

$\checkmark \quad$ Student attitudes toward classroom music are not only positively enhanced, but levels of interest and motivation are sustained across multiple academic years.

$\checkmark$ Students who received hands-on instruction had greater comprehension of musical concepts compared with students taught with traditional approaches and methods.

$\checkmark$ Music instruction provided through a technology assisted program contributes to a sense of professional development and personal growth on the part of the music educators.

$\checkmark$ Technology improved student concentration, maximized time on-task, developed and enhanced cooperative learning, and fostered higher level thinking skills.

The above study confirms the fact that for successful computer technology integration in music education, there must be a sound approach to integrating process in the curriculum. The approach must be intentional and must target two key factors; the educational goal and the appropriate technology tool to effect the goal. The question one must ask is; what are the educational goals for music teaching in the Colleges of Education in Ghana, and what available technologies are prescribed for music lesson delivery? To answer this question, this study looked at the prospects of computer technology in Colleges of Education in the Volta Region. The colleges of education in Ghana are basically mandated to train professional teachers for basic schools. Teachers graduating from these colleges are expected to be equipped with the pre-requisite knowledge that will impact on basic school pupils to prepare them for future further education. Music education forms part of the curriculum for the training of these professional teachers. Over the years, teaching of music in both training institutions and basic schools has suffered many challenges. One major setback of music education Ghana is lack of interest not only by the students/pupils but also teachers who transmit the knowledge. Music education in Ghana has passed through many 
metamorphoses, Mereku (1999). Any new vision for teaching music should provide a good platform for self and collective interest generation; a phenomenon that encourages a paradigm shift from irritating pedagogies to a well refined concept of music appreciation and full participatory behavior.

\section{The state of computer application in music teaching in Colleges of Education in Ghana}

There is no doubt that the very leadership of Ghana has placed a strong emphasis on the role of ICT in contributing to the economy of the nation. The medium-term development plan of the country captured in the Ghana Poverty Reduction Strategy Paper (GPRS I\&II) and the Education Strategic Plan 2003-2015 applauded the use of ICT as a means of integrating the poor in the economy of Ghana (Government of Ghana, 2003). In the year 2004, Ghanaian Parliament passed into law ICT for Accelerated Development (ICT4AD) policy. In view of this policy, the Ministry of Education produced an ICT in education framework document to integrate ICTs in schools and colleges. The ICT in education policy for Ghana had a long gestation period. The policy development for the sector predates the national ICT policy. A committee set up by the Ministry of Education, Science and Sports outlined an ICT in education policy framework and produced a document that remained untouched for a long time.

The objectives of the policy were clearly spelled out as follows:

i. Ensuring that students have ICT literacy skills before coming out at each level of education

ii. Providing guidelines for integrating ICT tools at all levels of education

iii. Providing means of standardizing ICT resources for all schools

iv. Facilitating training of teachers and students in ICT

v. Determining the type and level of ICT needed by schools for teaching and administrative purposes.

vi. Promoting ICT as a learning tool in the school curriculum at all levels. (Government of Ghana, Ministerial ICT Policy statements, 2005)

Mangesi (2007), the commitment to improving the quality of education through ICTs is high both at the presidential and ministerial levels. Progress has been made on several fronts, but several other inhibiting factors exist including the following:

i. Access to ICTs still remains highly inadequate and unevenly distributed through Ghana, with an urban bias.

ii. The capacity of teachers and educators to deliver policy still remains low with many averse to adopting ICTs in the classroom or with inadequate skills

iii. There is a lack of adequate collaboration between the Ministry of Education and Ghana Education service or other implementation agencies such as ministries, departments, and agencies.

iv. There are inadequate partnerships and collaboration between the ministry and the private sector.

According to the draft copy of ICTE Policy, The introduction of ICTs into education and its development partners and other private sector agencies by the Ministry is primarily through the GES. Public sector initiatives all over the years have spanned pre-tertiary cutting across public and private schools and tertiary institutions. The major efforts have fundamentally been geared towards the deployment of ICTs to these facilities through the provision of computers and the establishment of ICT laboratories. Also, there have been several attempts by the private sector initiatives to set up Community based ICT centres. These however have been largely confined to urban areas with few available examples of how they have been used to support educational objectives. Apart from a few individual pilot projects initiated by Ghana Education Service, such as NEPAD E-Schools and computer for schools projects there is a wide gap between ICT integration in and colleges schools in peri-urban, urban and capital cities. There are other private and NGOs like World Links for Development, the Global Teenager Project, among others, whose initiatives have gone long way to promote ICTs use in some selected schools.

The draft revealed that in a study carried out to review and assess the ICT in Education Initiatives in Ghana, twenty initiatives were selected and their impact assessed to see what lessons could be learnt. Several positive achievements were noted.

- Initiatives contributed to a wider number of students and teachers acquiring ICT skills and developing strong interests in ICT and Science;

- Schools involved in the initiatives were motivated to expand the project and / or acquire more ICT equipment; a number of private-public partners, including Parent Teachers Associations (PTAs) and civil society collaborated in the efforts;

- Lessons learnt from initiatives provided good examples for other schools to introduce their own ICT programmes;

However, the initiated projects were not free of a number of challenges. At least half of the initiatives had been launched as pilots with none expanded into national initiatives therefore led to a number of implementation challenges as follow:

- Poor selection of schools without the involvement of GES / MoESS resulting in duplication and hence some schools having several parallel initiatives while others (especially those in the remote rural towns) had none 
- Lack of policy direction at all levels (schools, districts, national) for the integration of ICT in education;

- Heavy dependency on external funds, with most initiatives stopped after depletion of initial funding

- 'Dumping' of obsolete and inappropriate equipment as ' support' for the initiatives

- Low levels of ownership at the level of the schools, due to external motivations, and low levels of understanding on the part of recipients about the potentials of ICTs in education

- Lack of trained ICT personnel (including teachers) far below the numbers demanded to support the initiatives with most capacity building efforts one-off with no continuous trainings.

In another development, the draft policy seeks to ensure success and sustainability of ICT in Education projects not necessarily increasing the number of computers, but also basically supporting discrete educational objectives. In view of this lessons learned from the initiatives further highlighted the need for a coordinated, focused and properly managed approach to the adoption and utilization of ICTs. Such an approach could further improve the accessibility and delivery of quality education and better maximize the impact of ICTs in Education. By the year 2004, the then thirty eight (38) Teacher Training Colleges in Ghana were converted to Colleges of Education with the introduction of Information and Communication Technology as a subject. Initially, government supports for the establishment of Computer laboratories for Colleges of Education was not met with much enthusiasm; however, some private sector organizations established and managed computer centers in the colleges. Individual tutors from various departments were given initial training in order to facilitate the teaching of ICT in the colleges. The year 2008 there was a slight turn-around of technology integration in the colleges. Many colleges began establishing computer laboratories with the help of internally generated funds and the help from volunteers. The government of Ghana through the GIFEC Programme sent the first consignment of computers to all colleges with internet connections. Subsequently, many other computers and ICT related devices were allocated to all colleges of education for average readiness for technology integration.

One important variable of ICTs integration in colleges is availability of ICT infrastructure. For instance Norris, McQueen and Cutler (2003) revealed that appropriate access to technology infrastructure is another key factor in the effective technology integration process. In a related study Ottesen (2006) stated that one fundamental problem facing ICT integration in schools is the lack of computer infrastructure. In another study, Yildrim (2007) explained that teachers agreed that access to ICT infrastructure is one of the effective means to integrate ICT in classrooms. Carlson and Gadio (2002) stated that teachers are the key to whether technology is used appropriately and effectively. Appropriate use of ICT can catalyze the paradigmatic shift from teacher centered pedagogy to more effective learner centered pedagogy. Capacity building of teachers as well as administrators and managers can play a major role in enabling this shift. The focus of teacher training institute however should not be limited to training teachers on how to use ICT rather it should provide the teachers with the skills and expertise required to use ICT to teach a curriculum which is better suited to prepare students for the 21 st century. By the year 2004, the then thirty eight (38) Teacher Training Colleges in Ghana had been converted to Colleges of Education with the introduction of Information and Communication Technology as a subject. Initially, government supports for the establishment of Computer laboratories for Colleges of Education was not met with much enthusiasm; however, some private sector organizations such as OESTEC established and managed computer centers in the colleges.

The infrastructural development for the integration in the colleges of education at the time of ICT insertion was virtually inadequate. Initially, some colleges converted existing classrooms to computer laboratories. Some colleges had few computers donated by individuals and old students' unions without any proper accommodation to set them in. Many individual colleges had to struggle with their own internally generated funds to provide decent places for these computers. Some selected individual tutors from various departments including Social Sciences were given initial training in order to facilitate the teaching of ICT in the colleges. In the year 2008, there was a massive turn-around of technology integration in the colleges. Some of the colleges in the country began to establish computer laboratories with the help of internally generated funds and help from volunteers. The government of Ghana through the GIFEC initiative programme sent the first consignment of 20 computers each to all colleges with internet connectivity from K-Net Internet service, the then internet service provider for all colleges. Subsequently, many other computers and ICT related devices like projectors and projector screens, printers and scanners were allocated to all colleges of education.

GIFEC initiative employed the service of private IT companies such as ZEBRA and HITEC to supply these technology facilities to colleges. Currently, it is believed that through the support of government technology initiatives and colleges' own internal supports, some colleges can boast of two computer laboratories. It should be noted that all the above initiatives provided computers, printers, scanners and projectors and screens only. Other technological facilities like electronic keyboard, Digital recorders, Computer Assisted Instruction packages, teaching software packages are excluded. If there are any of these technological facilities in a college, then it came at the ingenuity of a tutor or as support from college administration. Monahan (2004), policy directions should have a major focus on creating and expanding the ICT infrastructure, while this helps the countries lay a foundation for integrating ICT, it results in an incredible influx of financial support for equipment but only a meager trickle for network support or staff training. He further stated that without a sound capacity building framework, the 
financial resources spent on building the infrastructure will go to waste. Important parameters that determine the success of ICT adoption in Education sector are the appropriateness of technologies, the suitability and quality of instructional materials and educational services made available, learning effectiveness and appropriation of new ways of work, and the cost benefit ratio. It is, therefore, important that policy makers are sensitized on the importance of incorporating these aspects within the plans for ICT in education at all levels.

The above set the pace for an ideal situation. The fact still remains that the building of ICT infrastructure still faces many challenges in the colleges of education. One would have wished that the central government of Ghana takes direct provision of technology infrastructure for colleges of education; but this is not the case. Individual colleges are given a lean way to apply for infrastructure development depending on the needs of each college. Administratively, any leader would like to apply for his/her priority in which case ICT infrastructure development may not be one of the opportunity cost.

\section{Music and teacher education in Ghana}

Amuah (2014), music education in Ghana was dated as far back as $19^{\text {th }}$ Century with the encounter with early Europeans. The process of music education started with the training of local teachers to teach simple western hymns and songs. This led to the emergence of choirs in the churches because the principal brain behind music school then was to prepare for church worship. Flolu (1994) also confirmed the assertion made by Amuah in his doctoral thesis when he stated "undoubtedly, Western education paid little attention to the social and cultural environment of African countries, but imposed on them an alien and abstract form of education. At each stage of pre-independence, education in Ghana was marked by definite and precise objectives which were geared to coincide with the interests of those it was intended to benefit. The curriculum of the earliest formal institutions, the Castle Schools, the first of which was opened at Elmina in 1644, was limited to reading, writing and arithmetic" (p. 57). He indicated that by 1848 the Basel Mission established a teacher training institution at Akropong, Akwapim. In 1876, other Missionaries such as the Wesleyan, the Anglican, the Bremen and the Catholic Missions also established similar institutions throughout the Gold Coast. He also stated "though the primary purpose was to train teachers, catechists and church workers, it was from these schools that scholars of various disciplines emerged as the curriculum gradually expanded to include science, agriculture and other humanities" (p. 63).

In a related study, Amuah (2014) pointed out that by the year 1927, the cooperate effort of the then Governor Guggisberg and Emmanuel Aggrey brought forth the introduction of music in the Achimota College where the choir and an orchestra performed only European pieces. In an attempt to meet the need of the colonial regime's policy of promoting African culture, in 1934, a pioneer Ghanaian Musicologist, Ephraim Amu was tasked for teaching of African songs in the music department of the college. In 1949, another break-through in music education was achieved. A three-year teacher education programme was introduced with the study of music as one of the courses. The course content was made up of practical courses in African music (drumming and piping) and the theory of Western music under the initiative of Amu. Nketia (1996) reiterated that from the insertion to the middle of 20th Century, no common curriculum for music education had been planned. The teaching of music in schools and colleges was left primarily to the resourcefulness and the passion of individual teachers. This process led to variations in delivery of music education from school to school or from area to area according to the impact of missionary activities. Wherever music was studied, it was based on the current fashion in England. It was also noted that the teaching of the movable doh and music appreciation was done by the help of gramophone records by only talented music teachers in Ghana (Nketia, 1966: p. 236).

Mereku (2000) further traced the history of music education in Ghana to the transfer of the music school from Achimota to the Kumasi College of Technology in 1951 and subsequently moved to the Specialist Training College at Winneba for training of Certificate ' $A$ ' teachers to enable them teach music in the then teacher training colleges. He stated that in 1973 the music department at Winneba was offered autonomy and moved to University College of Education (UCEW) Central Campus as the National Academy of Music. As the need for music teachers grew higher, a certificate course in music was introduced as an integral part of the teacher training at Komenda Training College in the year 1972 and in addition the National Academy of Music continued training teachers for secondary schools, initial teacher training colleges and the manpower for Ghana Education offices.

Amua (2000) indicated that in 1974 a prominent position was given to African Music in the schools' curriculum. The structure and content of educational curriculum was published to include music not as an independent subject but grouped with Dance, Drama and Religious Studies for Junior Secondary Schools and as an optional for Senior Secondary Schools. The programme for the Specialist Training College at Winneba was expanded and graduates were required to pass the British Licentiate of Royal School of Music (LRSM) diploma examination. As cited in Mereku (2000), Evans (1975) revealed how narrow the music education curriculum was from Achimota to Kumasi College of Technology where music was put under four main headings as Singing, Theory, Rhythmic Movement and Appreciation. Mereku stated 'in an interview with Mr. C. B. Wilson who was a student of E. Amu at the Kumasi College of Technology, he agrees that the teacher education curriculum only presented western aesthetic values that were related to nineteenth-century musical taste" In a related development, 
Flolu in his doctoral thesis quoted Ephraim Amu as found in a related study "The Position of Christianity in Modem Africa" in International Review of Missions, 1940, 29, 481, quoted by Mobley, 1970: 102: "I was trained for four years in one of our colleges in the Gold Coast as teacher and catechist. I started teaching without the faintest knowledge of any of our social and religious institutions; in fact the prevailing Christian attitude was to keep us far away from them as possible. What success would you expect of such a leader who leads men about whose life he knows nothing? Up to now the situation remains practically the same in the colleges for training teachers, catechists and ministers" (p. 65)

Mereku further explained that although the content of the Specialist Training College was modelled on the London Examination, the four year programme offered courses in the content studies and professional studies. In the Content Studies, he said that it included Harmony and Counterpoint, Orchestration, Music History and Literature, Aural Culture, Applied Music (Major instrument or Voice), Functional Piano (for non-piano major) and knowledge and functional use of African instruments (Drumming only). The Professional Studies involved the History of Western Music Education, School Music Repertoire and Teaching Practice. By 1986 the Content Studies remained the same while the Professional Studies was expanded to Comprehensive Musicianship Approach to the teaching of music. This change brought about the introduction of 1-Year Post Diploma Certificate in Education (PDCE) until 1992 when the National Academy of Music was absorbed into the University College of Education, Winneba as part of the Government's University Rationalization programme. Ohene-Okantah in his paper "In search of an African Philosophy of Music Education for Ghana" stated that even though the current Educational Reform in Ghana have called for Africanization of music of education, not much work has been done to explain the philosophical base for such Africanization. He was of the view that music education in any case must be basically rooted in African philosophy even if concepts, ideas and labels are barrowed from elsewhere. He again cited Reimer's Philosophy and African Music and explained that according Reimer, music education must be perceived as aesthetic education where:

a) Music makes meaning in and of itself without necessarily making reference to external ideas or objects

b) Such meaning is communicated through the overall import of the conglomerate of its parts-the expressive quality of music which is the sum total of the elements of music.

c) What music communicates is perceived through an understanding of how music works and is put together.

d) Perception of the expressive qualities of music endangers affective (emotional) response, which enhances the quality of life.

e) Music education exists first and foremost to develop every person's natural responsiveness (affective response) to the power of the art of music.

He therefore concluded that philosophy of aesthetic education as proposed by Reimer could have useful implications for the case of Ghana's music education; however, African philosophy of education should take African models of thinking and approaches to music making into consideration (Ohene-Okantah, 1997, pp. 3-4) Nyamful (2016) indicated that in search for the meaning of music in education, two dominant themes appear: musical meaning and its practical function. Drawing his conclusion from the views if Knlotman (2014), he stated that musical meaning has to do with the definitional, philosophical construct and as a practical and functional subject. He clearly observed that in today's educational climate, heavy emphasis is given mainly to assessment of cognitive outcomes to the neglect of both the affective and psychomotor. This observation is rightly upheld in Ghana where school assessment in music education is heavily focused on the cognitive domain. In sum, thus, he said "the benefit of music education lies in not only being musical but having a better understanding of one's self: the understanding of art and the world. When such training is coupled with ICT application, benefits can be far reaching. This, however, is not the case with the study and learning of music in Ghanaian schools" (Nyamful, 2016, pp. 63)

Amuah (2014) revealed that the power of basic music education in Ghanaian schools and colleges has weaned significant progress, having been placed under Music and Dance in the curricular, and grouped with other disciplines such as Pattern Making and Visual Arts, under the broad tag - Creative Arts. Currently, the subject features only in the lower primary schools and has no place in the Junior High Schools. It is also noted that the new syllabus designated for the course is unexplainable. Teachers therefore find it difficult to translate the content of the syllabus in practical terms. In the Senior High Schools the subject music is an option. Music is not taught in isolation in Colleges of Education in Ghana. The music and dance course outline as prescribed by Institute of Education University of Cape Coast for the Colleges of Education in Ghana is designed to cover three-semester duration of music education programme. The first of the three-semester courses is titled Music and Dance with the course code PRA 121. The content of this course is compulsory in the second semester of the first year training component. Principles and Methods of Teaching the Performing Arts1 and 2 with course codes PRA 211 and PRA 221 are taken as elective in second year first and second semesters respectively. The first year first semester music course seeks to equip students with generative processes, also known as rudiments, to expose students to music while the second year first semester prepares students on methodology to equip the beneficiaries with music teaching methodological skills. Below are the various specific course objectives for Music and Dance in the first 
and second years:

First year (Level 100) second semester:

a. Develop skills of discriminatory listening and observing

b. Appreciate the expressive qualities of the performing arts

c. Appreciate the relationship between different elements of music, dance and dance

d. Develop their creative abilities through their interaction with the elements of music, dance and drama

e. Examine the value of the performing arts

Second year (Level 200) First semester:

a. Appreciate the value and nature of the performing arts

b. Acquire competencies and skills which will enable them to compose simple rhythms, melodies and movement patterns for school pupils.

Second year (Level 200) Second semester:

a) Acquire competencies and skills which will enable them to develop their own strategies for Performing Arts teaching in basic schools in Ghana.

b) Acquire skills and strategies necessary in organising and directing creative activities among basic school pupils.

The content of the syllabus therefore concentrates largely on a brief rudiments, African music and methodology. In summary, the music and teacher education in Ghana cannot be overemphasized. It is very clear from the discourse that music education in Ghana has suffered a lot of influence from the colonial activities and even today the new educational reform is not totally free from such influences. The various course contents for music education over the years in teacher training institutions have seen little or no computer technology impact in the teaching of music. The colleges of education music syllabus seemed woefully inadequate for preparing professional music teachers for music education challenges of this $21^{\text {st }}$ century. Finally, music education over the years has not seen a clear educational direction even though many educational policies claimed to provide means for it. The way forward could be allowing music as independent discipline not clustered with other disciplines. There is the need for much advocacy for deliberate progressive study of music from basic school to tertiary level rather than the checkered system of the day.

\section{Research Design}

The research was conducted using the Descriptive Survey design. According to Marilyn Zurmuehlin Working Papers in Art Education1 (1981), a descriptive survey is a research design that attempts to establish the range and distribution of some social characteristics, such as education or training, occupation, and location, and to discover how these characteristics may be related to certain behavior patterns or attitudes. The design was found suitable since such a research describes and predicts phenomena without manipulating factors that influence the phenomena (Amedahe, 2002). The ultimate goal of this research was to find out the usage of computer technology in the teaching of music in colleges of Education in Ghana in the Volta Region, explain the present computer technology usage in music education as well as to outline the prospects of computer technology application in music education. In addition, the study was envisaged to make a change in the way and direction public sector led ICT initiatives for colleges and school are undertaken. Razavieh (1990) came out that descriptive research studies are designed to obtain information concerning the current state of affairs. Such a study is undertaken in order to ascertain and be able to describe the characteristics of the variables of interest in a situation. Its purpose is to learn about a large population by surveying a sample of that population; describe, clarify and interpret aspects of education as they presently exist.

A descriptive survey design was chosen because of the economy of the design, the rapid turnaround time in data collection (Creswell, 2003) and the ease of data interpretation by the use of simple descriptive statistics. Again Creswell was with the view that choosing descriptive survey design allows for more confidentiality with those being surveyed and furthermore provides a meaningful picture of events and seeks to explain people's perceptions and behaviour on the bases of the data collected. Schwarz (1999), despite the successes of using this design for the research, difficulties associated with such a design needs to be addressed. One problem is that some people may intentionally misrepresent the facts in order to present a favourable impression to the researcher. Sometimes inability of respondents to articulate their thoughts clearly and poor research instruments could be factors that affect the research outcome. Nonetheless, this is addressed in view of using a variety of instruments such as face-to-face interviews, telephone interviews and written questionnaire to collect data from a variety of sources.

\section{Sources of Data}

The research made use of two sources of data namely primary source and secondary source. The primary source of data for the research was the data obtained from the participants through questionnaire, interview and observation made by the researcher. The secondary source of data were taken from reports of studies done on 
computer technology in education, especially with regards to teaching of music in Colleges of Education in Ghana and elsewhere, information from the internet as well as other relevant studies on the activities under study, preliminary studies done by the Information and Communication Technologies in Education Programmes Unit (ICTEPU) of the Ministry of Education Science and Sports (MOESS) on ICT initiatives in Ghanaian Schools (National ICT4AD policy, 2004).

\section{Population}

The survey was conducted in seven (7) Public Colleges of Education in the Volta Region of Ghana. The study involved music tutors, elective music students and level 200 students who studied music in the first year first semester. The seven Public Colleges of Education that were used in study were:

1. Akatsi College of Education, Akatsi (AKATSICO)

2. St. Francis College of Education, Hohoe (FRANCO)

3. St. Teresa's College of Education, Hohoe (TERESCO)

4. Jasikan College of Education, Jasikan (JASICO)

5. Peki College of Education, Peki (GOVCO)

6. E. P. College of Education, Amedzofe (AMECO)

7. Dambai College of Education, Dambai (DATCO)

The total number of participants in the study was 147 comprising of seven (7) music tutors from the seven selected colleges, 32 elective music students from two colleges (12 students in GOVCO and 20 students in FRANCO in second year while no student offered music as elective subject in the rest of the colleges) and 108 level 200 students from six (6) of the colleges.

The table below shows the summary of the sampled population for the study.

\section{Table 1: Sampled Population}

\section{Sample and Sampling Techniques}

A combination of sampling techniques was used for the research. Purposive sampling was used to select the seven (7) Colleges of Education for the study. This was done by selecting all the seven public colleges in the Volta Region. The same sampling technique was used to select the 32 level two hundred (200) elective music students and seven (7) music tutors from the seven (7) selected colleges. The purposive sampling technique was chosen for the study because the subjects selected satisfied certain qualities which are not randomly distributed but they exhibit most of the characteristics of interest to the study (Amedahe, 2000). It must be noted however that the choice of the Colleges of Education and the music education were based on prior knowledge of the researcher as one of the music tutors teaching in Peki College of Education. Simple Random Sampling Technique was used to select the twenty (20) level two hundred (200) students who studied music in the first year from each college. Two (2) students were randomly selected from each class in each college and based on gender i.e. one male trainee and one female trainee. This was done by paper folding method that indicated "YES" or "NO" options. Simple random sampling technique gave all units of this target population an equal chance of being selected. It is said to be very reliable, with high degree of representativeness and generalization of research results (Amedahe, 2000).

\section{Research Instrument}

The main instruments that were employed to obtain data for the study were: questionnaire, interview and observation.

\section{Questionnaire}

In this study, the questionnaire sought to collect background information of the respondents. It included both closeended and open-ended items. There were two categories of questionnaire administered; questionnaire for the music tutor and questionnaire for the music students. The questionnaire also covered issues very pertinent to the unraveling of the research problem. The music tutor's questionnaire was focused on the background information on the availability of computer technology facilities in the colleges, professional qualification of music tutors, teaching experiences, tutor competence in the use computer technology and attitudes towards the use of computer technology in music education. The questionnaire for the music students on the other hand sought to generate responses that validate the information given by the music tutors. It touched on issues of technological resources available for learning music and accessibility of the facilities to the music students. The researcher chose questionnaire because it allowed respondents to express their views about a particular topic since some of its items were open ended. It also saved the researcher's time and lengthy explanations of item since the respondents responded to the items independently. The anonymity (nature of confidentiality) of questionnaire was also considered a relevant issue which made it a preferred option. The general benefits of a questionnaire which the researcher thought to make it appropriate were: consistency of presentation of questions to the respondents, a greater perception of anonymity for the respondents and less time consuming to administer.

\section{Interview}

The purpose of an interview was to find out what precise ideas the participants held on the use of computer 
technology in music education. To obtain additional data for the study, a semi-structured interview guide was prepared. This was done to seek information from individuals such as Assessment officers of the colleges selected, students and tutors other than selected participants and people whose views were very much of help to the cause of this research and were connected with activities of the institutions under study. The researcher employed oral interview to seek more information about the physical presence and the use of computer technology tools in the classroom. This was done to enable the researcher get more first-hand information that have not been covered by the questionnaire and could best be explained orally than writing. In all, twenty (20) participants were interviewed.

\section{Observation}

The observation was prepared to identify issues, activities and other happening of interest, as far as the study is concerned, which fed into the questionnaire and interviews. The researcher intended to use observation for two reasons:

i) Ascertain the fact about the physical presence and availability of computer technology in the selected colleges as recorded in the questionnaire and interview.

ii) To gather data on practical teaching of music lessons and how computer technology was used during lesson delivery as well as practical application of computer technology and other musical technologies in students' campus life.

\section{Data Collection Process}

The researcher took eight (8) weeks to collect data for the study. In the first week, preliminary contacts were made with the Heads of Departments and Music tutors of seven (7) selected public Colleges of Education in the Volta Region. Due to the vastness of study area, this early contacts were made through telephone calls. The purpose and significance of the research was discussed with them and permission as well as their support sought for the exercise. Specific times to carry out the exercise in selected colleges were fixed. Initially, the researcher intended to use two weeks for the administration and collection of completed questionnaire but it turned to cover four weeks. The questionnaire was administered in the second week to the students and music tutors of the selected colleges. Only three colleges were able to meet the deadline of two weeks of administration and collection of completed questionnaire while the rest four presented the completed questionnaire within the sixth week. The collection of the completed questionnaires from each college was done by courtesy of a volunteer on behalf of the researcher. The researcher in the midst of the apparent delay in completion of the questionnaire, gave the respondents enough time to respond to the questionnaire so that they were not forced to respond to it 'under pressure' and secondly to ensure anonymity of respondents and hopefully elicited more genuine response from them.

The interview sessions with selected respondents took four weeks. Fourteen (14) selected interviewees were contacted in the third week of the data collection process. Eight (8) of the interviewees consisting five (5) Assessment officers and three (3) Heads of Departments were contacted through telephone calls while six (6) others made up of five Heads of Departments and three Assessment officers were met face to face by the researcher. The purpose and significance of the research was discussed and specific times to carry out the interviews fixed. The researcher interviewed people on individual bases and also groups such as class of students (seven classes that were observed). During the interview, responses were recorded manually and also with the help of a mini digital recorder and call record system of a mobile phone. The last interview was carried out in the eighth week. The results of the interview were used to confirm the responses of music tutors and students on the questionnaire.

The researcher used the observation to solicit verification of physical presence of computer technology in the seven participating colleges. The observations were done during music lessons. In each of the seven colleges, the researcher observed one music lesson. The following were observed:

a) Type of computer technology available during lesson delivery

b) The use of available computer technology in lesson delivery and

c) Students' response during lesson delivery.

The observations began alongside the interview during the fourth week. It became necessary to combine the two instruments at the same time due to the high cost element of travelling from college to college. The researcher arrived early enough to observe the classroom environment and also tested some of the equipment before lectures. The observation guide was used (see Appendix C, pp. 117). The data collected through the observations were compared with the responses provided on the questionnaire and were used to confirm the research findings and provision of appropriate recommendations.

\section{Data Analysis}

The researcher employed descriptive statistical methods to analyze the data. The data obtained were edited, coded and entered into a computer and organized around a number of research questions raised in Chapter 1 using tables. The information collected was tabulated in frequency tables and expressed in percentages for the quantitative data interpretation and discussion. The tables brought out the true picture and quick visual impression of the research results. Recorded interviews were transcribed, and together with textual data from interviews were analyzed and 
discussed to corroborate the data obtained from the questionnaire. The observation data collected were also analyzed in line with the questionnaire for confirmation of availability of computer technology and its use and finally discussed under the related themes.

Tutor teaching experience and professional qualification

Table below shows the responses in terms of the state of the tutors' teaching experiences and their professional qualifications.

Table 1: Tutor teaching experience and professional Qualification

\begin{tabular}{|c|c|c|c|c|c|c|c|}
\hline College & $\begin{array}{l}\text { M.Phil. (Music } \\
\text { Education) }\end{array}$ & $\begin{array}{c}\text { M.A } \\
\text { (Music) }\end{array}$ & $\begin{array}{l}\text { M.ED } \\
\text { (Music) }\end{array}$ & $\begin{array}{c}\text { B.ED/BA } \\
\text { (Music) }\end{array}$ & $\begin{array}{c}\text { Diploma } \\
\text { (Music) }\end{array}$ & $\begin{array}{c}\text { Certificate } \\
\text { (Music) }\end{array}$ & Total \\
\hline $0-2$ years & 0 & 0 & 0 & 0 & 0 & 0 & $\mathbf{0}$ \\
\hline $3-4$ years & 0 & 0 & 0 & 1 & 0 & 0 & 1 \\
\hline $5-9$ years & 0 & 0 & 2 & 0 & 0 & 0 & 2 \\
\hline $\begin{array}{ll}\text { Over } 10 \\
\text { years }\end{array}$ & 4 & 0 & 0 & 0 & 0 & 0 & 4 \\
\hline Total & 4 & $\mathbf{0}$ & 2 & 1 & $\mathbf{0}$ & $\mathbf{0}$ & 7 \\
\hline
\end{tabular}

Source: Field of Study, 2020

Table 1 indicates the teaching experience and professional qualification of music tutors. According to the table, four (4) tutors (54.1\%) had over 10 years teaching experience with M.Phil. (Music Education) degree qualification, seven (2) tutors (28.6\%) had 5-9 years teaching experience with M.ED (Music) degree qualification and 1 tutor (14.3\%) had 3-4 years' experience in teaching with B.ED (Music) degree qualification. In line with the status and the harmonized scheme of the Colleges of Education in Ghana, the minimum qualification for a tutor is masters' degree. The findings of the table revealed that out of the seven (7) tutors who responded, six (6) representing $85.7 \%$ are duly qualified and one (1) representing $12.5 \%$ has not met the requirement. This implies that almost $90 \%$ of the sampled colleges have no challenges in terms of tutor qualification. In terms of tutor's teaching experience, majority of the tutors had gained teaching experience over seven (7) years which places colleges of education in a comfortable position for effective delivery.

The state of technology in music education in Colleges of Education in Ghana

The tables below present responses from music students and music tutors regarding the availability of technology facilities and their usage in seven (7) public Colleges of Education in the Volta Region

Table 2: Students' response regarding availability of technological facilities and their usage

\begin{tabular}{lcccc}
$\begin{array}{l}\text { Type of } \\
\text { Technology }\end{array}$ & $\begin{array}{c}\text { Availability of Technology in } \\
\text { Colleges } \\
\text { No. of colleges with } \\
\text { tech. } \\
(\mathbf{n = 7 )}\end{array}$ & $\%$ & $\begin{array}{c}\text { No. of Colleges Using tech. } \\
(\mathbf{n}=7)\end{array}$ & $\%$ \\
\hline Computer & 7 & $100 \%$ & 1 & $14.3 \%$ \\
Electronic Keyboard & 6 & $85.7 \%$ & 5 & $71.4 \%$ \\
Musical Digital Recorder & 2 & $28.6 \%$ & 1 & $14.3 \%$ \\
Others (drums, radio, CDs, & 4 & $57.1 \%$ & 3 & $42.9 \%$
\end{tabular}

flutes etc.)

\section{Source: Field Study, 2020}

Table 2 illustrates students' responses regarding availability of technological facilities and their usage in music education in their colleges. Seven (7) colleges responded positive to availability of computers representing $100 \%, 6$ colleges representing $85.7 \%$ confirmed having electronic keyboards, only two (2) colleges with $28.6 \%$ had Musical Digital Recorders and four (4) colleges agreed having other technologies (drums, CDs, etc) representing $57.1 \%$.

As indicated by the table above, out of seven (7) colleges with computers, one (1) college (14.3\%) only agreed using computers in teaching music, five (5) colleges $(71.4 \%)$ agreed using electronic keyboard during music lessons, one (1) college representing 14.3\% agreed using Musical Digital Recorders and three (3) colleges representing $42.9 \%$ agreed to have being using other technologies (drums, CDs, etc.) for music education. 
Table 3: Music teachers' response regarding music technology equipment available in colleges and their usage

\begin{tabular}{lcccc}
\hline $\begin{array}{l}\text { Type of } \\
\text { Technology }\end{array}$ & $\begin{array}{l}\text { Availability of Technology in } \\
\text { Colleges } \\
\text { No. of colleges with tech. } \\
(\mathbf{n = 7 )}\end{array}$ & $\%$ & $\begin{array}{c}\text { Usage } \\
\text { No. of Colleges Using } \\
\text { tech. }(\mathbf{n}=\mathbf{7})\end{array}$ & $\%$ \\
\hline Computer & 7 & $100 \%$ & 7 & $100 \%$ \\
Electronic Keyboard & 6 & $85.7 \%$ & 5 & $71.4 \%$ \\
Music Software & 7 & $100 \%$ & 7 & $100 \%$ \\
Musical Digital Recorder & 1 & $14.3 \%$ & 1 & $14.3 \%$ \\
Others (drums, radio, CDs, & 3 & $57.1 \%$ & 3 & $42.9 \%$
\end{tabular}

flutes etc.)

\section{Source: Field Study, 2020}

Table 3 shows Music Tutors' responses regarding availability of technological facilities and their usage in music education in their colleges. Seven (7) music tutors agreed having computer in their colleges representing $100 \%$, contrary to students' response of six (6) colleges $(85.7 \%)$ with electronic keyboards, seven (7) music tutors responded positively representing $100 \%$. Again, while students of two (2) colleges $(28.6 \%)$ only confirmed having Musical Digital Recorder, only one (1) tutor (14.3\%) agreed to have Musical Digital Recorder in college. Seven (7) music tutors $(100 \%)$ indicated that their colleges had music software and only three (3) music tutors confirmed having other technologies.

In the case of technology usage, seven (7) music tutors agreed to have been using computers, five (5) tutors agreed using electronic keyboard (71.4\%) and seven (7) confirmed using music software representing $100 \%$ each, only one (1) music tutor confirmed using Musical Digital Recorder and three (3) tutors indicated that they use other technologies in their colleges.

The role of computers in music instruction in colleges of education

This section shows responses of students and tutors regarding the role of computer technology in music instruction in seven (7) public colleges of education in the Volta Region. Areas covered were: Music tutors' response on their formal training as music educators to handle music technology, Students' response on curriculum areas supported through the use of music technology, Music tutors' response to types of technology and the curriculum areas supported through the use of technology, and Music tutors' response regarding the Basic /simple use of applications for the purposes of Music Education.

Table 4: Music tutors' response on their formal training as music educators to handle music technology

\begin{tabular}{|c|c|c|c|c|}
\hline \multirow[t]{2}{*}{ Music Technology } & \multicolumn{2}{|c|}{$\begin{array}{l}\text { No. of Tutors trained to } \\
\text { handle music technology }\end{array}$} & \multicolumn{2}{|c|}{$\begin{array}{l}\text { Tutors Not-trained to handle } \\
\text { music technology }\end{array}$} \\
\hline & $(n=7)$ & $\%$ & $(n=7)$ & $\%$ \\
\hline Computer & 3 & $42.9 \%$ & 4 & $57.1 \%$ \\
\hline Electronic Keyboard & 7 & $100 \%$ & 0 & $0 \%$ \\
\hline Music Software & 3 & $42.9 \%$ & 4 & $57.1 \%$ \\
\hline Musical Digital Recorders & 0 & 0 & 0 & $0.0 \%$ \\
\hline Others e.g. drums, radio, flute, CDs, etc. & 0 & 0 & 0 & $0.0 \%$ \\
\hline
\end{tabular}

Source: Field Study, 2020

Table 4 shows music tutors' response regarding their formal training as music educators to handle music technology. According to the table, three (3) music tutors representing $42.9 \%$ had formal training to handle computer while 4 representing 57.1 had no formal training. Seven (7) music tutors had formal training in electronic keyboard representing 100\%. Three (3) music tutors representing 42.9\% had formal training in Music software while four (4) had no formal training. No music tutor had formal training in Musical Digital Recording and others as indicated by the table. 
Table 5: Students' response on curriculum areas supported through the use of music technology.

Music Curriculum areas supported through music Students Percentage
technology.

Frequency

$(\mathbf{n}=140)$

Theory of Music (elements of music)

Composition (Melody and part writing, skills training)

History of Music (Western and Contemporary Ghana)

Practicals (Voice training, Piano playing part singing, sight singing, Aurals)

\begin{tabular}{lcc} 
None & 48 & $34.3 \%$ \\
\hline Total & 140 & $100 \%$
\end{tabular}

Source: Field Study, 2020

Table 5 displays students' responses on curriculum areas supported through the use of music technology. Out of 140 students sampled, fifteen (15) students representing $10.7 \%$ agreed that music technology supports the teaching of music theory, twenty-two (22) students representing $15.7 \%$ attested to music technology support for composition, only nine (9) students (6.4\%) agreed that music technology supports the teaching of History of Music. Forty-six (46) students also agreed that Practical are conducted using music technology representing $32.9 \%$ and forty-eight (48) students representing the largest percentage of $34.3 \%$ confirmed that music technology was completely absent from all curriculum areas in their music lessons.

Table 6: Music tutors' response to types of technology and the curriculum areas supported through the use of technology

\begin{tabular}{|c|c|c|c|}
\hline $\begin{array}{l}\text { Music } \\
\text { Technology } \\
\text { available }\end{array}$ & $\begin{array}{l}\text { Music Curriculum areas supported through music } \\
\text { technology }\end{array}$ & $\begin{array}{l}\text { No. of colleges } \\
N=7\end{array}$ & $\%$ \\
\hline Computer & $\begin{array}{l}\text { Composition, piano skills, lesson presentation, CBT, } \\
\text { WBT. }\end{array}$ & 7 & $100 \%$ \\
\hline $\begin{array}{l}\text { Electronic } \\
\text { keyboard }\end{array}$ & $\begin{array}{l}\text { Theory ; scales, melody writing playback, Chord } \\
\text { progressions, cadences }\end{array}$ & 7 & $100 \%$ \\
\hline Musical Digital Recorder & Aurals, Sight singing, scales, melody writing & 1 & $14.3 \%$ \\
\hline $\begin{array}{l}\text { Others i.e. drums, CDs, } \\
\text { flutes etc. }\end{array}$ & Rhythm practice, pitch etc. & 1 & $14.3 \%$ \\
\hline
\end{tabular}

\section{Source: Field Study, 2020}

Table 6 shows music tutors' response to types of technology and the curriculum areas supported through the use of technology. Seven (7) music tutors representing 100\% agreed that computer is used in composition, piano skills, lesson presentation, CBT and WBT, again, seven (7) tutors (100\%) agreed using electronic keyboard in music theory; scales, melody writing, playback, chord progressions and cadences. Only one (1) tutor agreed using Musical Digital Recorder for aural and sight singing. One (1) tutor (14.3\%) also confirmed using other technologies in teaching rhythm practice, pitch, etc. representing $14.3 \%$.

Table 7: Music tutors' response regarding the Basic /simple use of applications for the purposes of Music Education

\begin{tabular}{lccccc} 
Item & $\begin{array}{c}\mathbf{4} \\
\text { (Excellent) }\end{array}$ & $\begin{array}{c}\mathbf{3} \\
\text { (V. Good) }\end{array}$ & $\begin{array}{c}\mathbf{2} \\
\text { (Good) }\end{array}$ & $\begin{array}{c}\mathbf{1} \\
\text { (Fair) }\end{array}$ & $\begin{array}{c}\text { 0 } \\
\text { (No capability) }\end{array}$ \\
preparing papers & 3 & 1 & 3 & 0 & 0 \\
- Powent/ budget/accounts & 3 & 0 & 1 & 2 & 1 \\
Instructions & 1 & 1 & 1 & 1 & 3 \\
& 2 & 1 & 2 & 1 & 1 \\
& 0 & 1 & 1 & 1 & 4 \\
\hline
\end{tabular}

Word processing - preparing papers

Spreadsheet - assessment/ budget/accounts

Presentation tools - PowerPoint for teaching

Basic E-mailing

Computer Assisted Instructions

Others

Source: Field Study, 2020

Table 7 displays tutors' response regarding basic use of computer applications for the purposes of music education. Three (3) out of seven (7) tutors (42.9\%) had excellent in the use of word processor; only one (1) tutor $(14.3 \%)$ had very good, three (3) tutors $(42.9 \%)$ had good use of word processor application and no tutor had fair or no capability in the use of word processor. For the purpose of assessment, three (3) tutors (42.9\%) had excellent use of spread sheet applications while no tutor had very good. One (1) tutor (14.3\%) had good, $2(28.6 \%)$ had fair use of spread sheet application and One (1) had no capability for the use of the application. Table 9 again revealed that only two (2) tutors representing $28.6 \%$ had excellent knowledge and use of presentation tools like PowerPoint for lesson delivery, $1(14.3 \%)$ had very good, 1 (14.3\%) had good, 1 tutor $(14.3 \%)$ had fair and two (2) tutors representing $28.6 \%$ had no capability of using presentation tools. For purposes of basic e-mailing, only two (2) 
tutors representing $28.6 \%$ used it excellently, 1 tutor representing $14.2 \%$ had very good use while two (2) tutors $(28.6 \%)$ had good knowledge and use. Fair and no capability had 1 tutor (14.3\%) each respectively. For Computer Assisted Instruction, no tutor had excellent use but two (2) representing $28.6 \%$ had very good use. 1 music tutor $(14.3 \%)$ had good use, one (2) tutors $(28.6 \%)$ had fair use and two (2) tutors (28.6\%) had no capability. Only one (1) tutor $(14.3 \%)$ used other applications for the purposes of music education.

\section{Accessibility of computer technology to colleges of education in Ghana}

Table 8 shows the responses of music tutors' frequent use of technology for purpose of music education.

Table 8: Frequency of music tutor's use of technology tools for education

\begin{tabular}{lcccc} 
Educational Purposes & $\begin{array}{c}\text { Very Often } \\
\text { (everyday) }\end{array}$ & $\begin{array}{c}\text { Often } \\
\text { (twice a } \\
\text { week) }\end{array}$ & $\begin{array}{c}\text { Seldom (few } \\
\text { week/months) }\end{array}$ & Never \\
\hline
\end{tabular}

\begin{tabular}{|c|c|c|c|c|}
\hline $\begin{array}{l}\text { Communication with students/family/friends } \\
\text { (charting) }\end{array}$ & 6 & 0 & 1 & 0 \\
\hline $\begin{array}{l}\text { Monitoring and evaluating progress of students } \\
\text { performances or keeping tracks of educational } \\
\text { events }\end{array}$ & 2 & 0 & 4 & 1 \\
\hline $\begin{array}{l}\text { Engaging others on Collaborative projects } \\
\text { (learning) }\end{array}$ & 0 & 2 & 2 & 3 \\
\hline $\begin{array}{l}\text { Use internet when preparing for Music lessons, } \\
\text { Workshops and Seminars }\end{array}$ & 3 & 1 & 2 & 1 \\
\hline $\begin{array}{l}\text { Search for general information on topics of } \\
\text { personal interest and music educational } \\
\text { materials }\end{array}$ & 2 & 2 & 1 & 2 \\
\hline
\end{tabular}

\section{Source: Field Study, 2020}

For communication, six (6) tutors representing $85.7 \%$ used technology very often and 1 tutor (14.3\%) seldom use technology. Monitoring and evaluating; two (2) tutors $(28.6 \%)$ very often used technology for monitoring and evaluating students, four (4) tutors (57.1\%) seldomly used it and one (1) tutor (14.3\%) never used technology for monitoring and evaluation progress of students performances. For collaborative projects, no tutor used technology very often, two (2) tutors $(28.6 \%)$ used it often, two (2) tutors $(28.6 \%)$ seldomly used technology and three (3) tutors representing $42.9 \%$ never used technology for collaborative works. Using internet when preparing for Music lessons, Workshops and Seminars, 3 tutors (42.9\%) used internet very often, only 1 tutor (14.3\%) often used internet, $2(28.6 \%)$ seldomly used it and 1 tutor (14.3\%) never used the internet. For the purposes of searching for general information on topics of personal interest and music educational materials, two (2) tutors (28.6\%) used it very often, 2 (28.6\%) used it often, 1 (14.3\%) Seldomly used it and two (2) tutors $(28.6 \%)$ out of $7(100 \%)$ never used it.

Prospects for computer usage in Music Education in Colleges of education in Ghana

The below brings to fore the music curriculum areas where students and tutors experience difficulty. Table 9: Music curriculum areas (topics) where students experience difficulty

\begin{tabular}{lcc}
\hline Difficult music topics & Response $(\mathbf{n}=\mathbf{1 4 0})$ & Percentage $(\mathbf{\%})$ \\
\hline Theory of music & 25 & $17.9 \%$ \\
History of music & 32 & $22.9 \%$ \\
Composition & 30 & $21.4 \%$ \\
Practicals & 26 & $18.6 \%$ \\
Others & 7 & $5.0 \%$ \\
\hline Total & $\mathbf{1 4 0}$ & $\mathbf{1 0 0} \%$ \\
\hline
\end{tabular}

Source: Field Study, 2020

Table 9 shows responses of students regarding music curriculum areas where they experience difficulty. The highest difficulty area indicated by students was History of Music recording thirty-two (32) students representing $22.9 \%$. The second highest difficulty area was Composition with thirty (30) students representing $21.4 \%$. Next is Practicals with twenty-six (26) students (18.6\%) followed by the Theory of Music with twenty-five (25) students (17.9\%). The lowest was others recording seven (7) students representing 5.0\%. 
Table 10: Tutors' response on most challenging music topics in music education

\begin{tabular}{lcc}
\hline Most challenging music topics & Response $(\mathbf{n}=\mathbf{7})$ & Percentage $(\mathbf{\%})$ \\
\hline Theory of music & - & $0.0 \%$ \\
History of music & - & $0.0 \%$ \\
Composition & - & $0.0 \%$ \\
Practicals & 2 & $28.6 \%$ \\
Others & - & $00.0 \%$ \\
\hline
\end{tabular}

Source: Field Study, 2020

Table 10 constitutes responses from tutors regarding the most challenging music topics in music education. The table revealed that out of seven (7) music tutors sampled, only two (2) agreed that having challenges in Music Practicals representing $28.6 \%$. No tutor experienced any challenges in Theory, Composition and History of music respectively.

Table 11: Tutors' response regarding introduction of music technology into the current curriculum

\begin{tabular}{|c|c|c|}
\hline Status & $\begin{array}{c}\text { Positive response } \\
\quad \mathrm{N}=7\end{array}$ & $\begin{array}{c}\text { Negative response } \\
\quad \mathrm{N}=7\end{array}$ \\
\hline Tutors & 7 & - \\
\hline
\end{tabular}

Source: Field Study, 2020

Table 11 looks at tutors' responses regarding introduction of music technology into the current curriculum. Seven (7) tutors out seven (7) sampled tutors responded positively representing $100 \%$.

Table 12: Students' response regarding introduction of music technology into the current curriculum

\begin{tabular}{|c|c|c|}
\hline Status & $\begin{array}{c}\text { Positive response } \\
\quad \mathrm{N}=140\end{array}$ & $\begin{array}{c}\text { Negative response } \\
N=140\end{array}$ \\
\hline Tutors & 119 & 21 \\
\hline
\end{tabular}

Source: Field Study, 2020

Table 12 shows students' response in regards to the introduction of music technology into the current curriculum. One hundred and nineteen (119) students representing 85\% were optimistic while twenty-one (21) students representing $15 \%$ were pessimistic.

The state of technology in music education in Colleges of Education in the Volta Region

In view of the first research question, this section looks at the data presented through the responses of music students and music tutors regarding the state of technology in Colleges of Education in Ghana. The section answers the question; what technological facilities and equipment (Computer, Electronic Keyboard, and Musical Digital Recorder) are available and what is their usage in the colleges?

Students' response regarding availability of computer technological facilities and their usage

As indicated in chapter four table 5, out of seven (7) colleges with computers, $(14.3 \%$ only agreed using computers in teaching music, $71.4 \%$ agreed using electronic keyboard during music lessons, $14.3 \%$ agreed using Musical Digital Recorders and $42.9 \%$ agreed to use other technologies for music education. From the findings, students confirmed availability of computer technology in all the selected colleges except other musical technologies that are few and vary from college to college. It was found out that, students in many of the colleges experience the use of electronic keyboard in music lessons while computer technology and other musical technologies use are far below average.

Music tutors' response regarding availability of computer technological facilities and their usage

In the case of technology usage, $100 \%$ of the music tutors agreed to have been using computers, $71.4 \%$ agreed using electronic keyboard and 100\% confirmed using music software. 14.3\% confirmed using Musical Digital Recorder and $42.9 \%$ indicated that they use other technologies (drums, CDs, flute, etc.) in their colleges. Like the students, tutors from all the participated colleges confirmed the availability of computer in all the colleges. From the observation and interview as well as the questionnaire, almost all tutors use computers for purposes of personal research rather than teaching of music. Other technological facilities are also used in terms of availability and ability to use.

From the data and analysis concerning the state of computer technology in music education, it is possible to say then that:

a) Computers are available in almost all the colleges of education sampled

b) Government ICT policy and initiative for colleges of education provides only computers to colleges without any consideration for provision of other equally necessary technology equipment for music education.

c) There is abysmal patronage of computer technological facilities and equipment in teaching music in 
the sampled colleges.

It also revealed that not all the sampled colleges have Electronic Keyboard, Musical Digital Recorder and other technologies for music education. Even though computer technology is common in all colleges, majority colleges do not use them for the purposes of music education.

\section{The role of computers in music instruction in colleges of education in the Volta Region}

In this section, the study discusses findings from music tutors regarding types of technology and curriculum areas supported through the use of technology, basic use of computer application for music education as well as the formal training as music educators to handle music technology. Oliver \& Towers, (1999) state that computer technologies have the capacity to provide support for customized educational programs to meet the needs of individual learners. Reeves \& Jonassen (1996) on the other hand make it clear that the influence of the technology on supporting how students learn will continue to increase. The emergence of ICTs as learning technologies has coincided with a growing awareness and recognition of alternative theories for learning.

\section{Students' response on curriculum areas supported through the use of music technology.}

Table 5 indicated students' responses on curriculum areas supported through the use of music technology. Out of 140 students sampled, $10.7 \%$ agreed that music technology supports the teaching of music theory, $15.7 \%$ attested to music technology support for composition and $6.4 \%$ agreed that music technology supports the teaching of History of Music. Again 32.9\% agreed that Practical are conducted using music technology and 34.3\% confirmed that music technology was completely absent from all curriculum areas in their music lessons. The findings showed clearly the discouraging situation in the use of computer technology in the teaching of music in the selected colleges. . The least area in the curriculum that experienced the lowest use of computer technology is the History of Music. This revealed an important consideration for teaching of music in the colleges of education. By this revelation, it is very clear that abstract teaching takes precedence over the technologically oriented lesson delivery.

\section{Music tutors' response on their formal training as music educators to handle music technology}

From table 6 collaborated by personal interviews with music tutors, it was revealed that $42.9 \%$ of the music tutors had formal training to handle computer technology while $57.1 \%$ had no formal training. $100 \%$ of music tutors had formal training in electronic keyboard. 42.9\% had formal training in Music software and 57.1\% had no formal training. No music tutor had formal training in Musical Digital Recording and others as indicated by the table. From personal interview and observation, the following were ascertained:

a) What they referred to as formal training in computer and music software were not acquired as part of courses studied during their formal training as music tutors but as part of their personal efforts outside the regular studies.

b) Apart from keyboard training which forms an integral part of the formal training, music tutors lack the necessary computer technological skills that enhance effective teaching and learning.

It implies therefore that tutors lack basic technological skills necessary for imparting knowledge to student using computer technology. They also therefore do not have the confidence to use those personally acquired technological skills during the delivery of music lesson.

\section{Music tutors' response to types of technology and the curriculum areas supported through the use of technology}

As regards responses for the type of technology and curriculum area supported by computer technology, Malachi (2007) said in his thesis "it is interesting to note that while teachers reported that they normally used computer technology to aid in their music instruction; students denied its use but only acknowledged the availability of computers in their schools. However, it was clear that the availability of these equipment did not necessarily mean that they were used in supplementing music instructions". Table 10 showed music tutors' response to types of technology and the curriculum areas supported through the use of technology. $100 \%$ agreed that computer is used in composition, piano skills, lesson presentation, CBT and WBT. Again, 100\% agreed using electronic keyboard in music theory; scales, melody writing, playback, chord progressions and cadences. Only $14.3 \%$ agreed using Musical Digital Recorder for aural and sight singing and 14.3\% also confirmed using other technologies in teaching rhythm practice, pitch, etc.

The researcher finds it interesting that the case of Colleges of Education in the Volta Region is not different from the findings of Malachi. Most of the tutors interviewed by the researcher to collaborate the findings of the questionnaire revealed that they lacked competence to handle the music technology facilities such as the computer. Tutors who responded that although they were comfortable with using the music facilities and equipment, unavailability of music software and other music computer technologies to the music department denied them the means to give exposure and individual attention to the students using computer technology in music lessons. Hence the findings of this research holds the view that majority of the music students hardly get the chance to use the 
technology to enhance teaching and learning.

Music tutors' response regarding the Basic /simple use of applications for the purposes of Music Education Table 7 displayed tutors' response regarding basic use of computer applications for the purposes of music education. In general, the findings revealed the problem of lack of competence of applying basic knowledge in simple computer applications to enhance delivery of music education. It is true that failure to grab these basic applications would throw the technology integration in education process into a complete jeopardy. The findings indicated that the least used applications are the Computer Assisted Instruction and the presentational applications which are dearer to the heart of music education and music technology instructions. By the above revelations, it is also clear that tutors of the selected colleges may resort to using traditional methods of educational instructions rather than the modern and more appropriate and convenience means.

\section{Accessibility of computer technology to colleges of education in the Volta Region}

The central assumption of constructivism is that learning is mediated by tools and signs (Duffy \& Cunningham, 1996; Ezell \& O'Keeffe, 1994). "Culture creates the tool, but the tool changes the culture. Participants in the culture appropriate these tools from their culture to meet their goals, and thereby transforming their participation in the culture" (Duffy \& Cunningham, 1996, p. 180).In view of this, in modern and digital world, every employee is expected to acquire basic skills in information and communication technology. This enhances work delivery resulting in efficiency, growth and development. Computer literacy is the level of expertise and familiarity someone has computers. Generally, computer literacy refers to the ability to use applications rather than to program. It is the knowledge and ability to use computers and technology efficiently. Competency in computer technology means being able to use a computer to perform the basic tasks needed to work with efficiency.

Again, it means being able to perform simple tasks with a computer e.g. Email, research, interaction with others via the internet. Creating and editing documents, spreadsheets, slide show (PowerPoint) etc. It is vital for the purposes of technology integration in education of which music education is no exception.

\section{Music tutors' frequent use of technology for purpose of music education.}

From findings, it is clear that apart from the purposes of communication as everyday routine, music tutors' frequent use of computer technology facilities fall below average. This presupposes tutors' lack of interest in the use of technology facilities in the classroom. It also exposes lack of awareness of the roles of computer technology in music education. Again tutors' reluctant use the facilities reveal lack of competent computer technological skills necessary for music instruction or education.

\section{Prospects for computer usage in Music Education in Colleges of education in Ghana}

Saven (2016) clearly stated "the role of the teacher for that matter music teacher has changed as the traditional education methods, techniques and applications have left its place to the student-centered methods, techniques and applications along with the $21^{\text {st }}$ Century. Teachers are no more source and share the information but do guide students to access information and manage the process". The prospects of computer usage in music education come with some deficiencies that cannot be overlooked in an effective technology integration process. These deficiencies involve music teacher's lack of knowledge on the use of computers, inappropriateness of the physical conditions of the class environment, insufficient number of computers for students, lack of software, lack computer programs and lack of technical assistance. Hence, for successful computer technology integration in music education, there must be a sound approach to integrating process in the curriculum. The approach must be intentional and must target two key factors; the educational goal and the appropriate technology tool to affect the goal. The next table, Table 13 brings to fore the music curriculum areas where students experience difficulty.

\section{Music curriculum areas (topics) where students experience difficulty}

Table 9 shows responses of students regarding music curriculum areas where they experience difficulty. The highest difficulty area recorded by students was History of Music recording with $22.9 \%$. The second highest difficulty area was Composition with $21.4 \%$ and Practicals gaining $18.6 \%$. The next difficulty area was the Theory of Music with $17.9 \%$ and the lowest was others with a record of $5.0 \%$. The next table which is table 15 , showed an interesting story which needs to be compared with table 14. It showed the responses of music tutors regarding most challenging topic or curriculum area.

\section{Tutors' response on most challenging music topics in music education}

Table 10 revealed that $28.6 \%$ of the selected tutors agreed having challenges in Music Practicals, however, no tutor experienced any challenges in Theory, Composition and History of music respectively. Comparing the responses of the two tables, it is clear that students have difficulty in understanding some curriculum areas in terms of music education; however, tutors on the other hand have no challenging curriculum areas. The implication of 
this is in two folds: either the students fail to understand the instructions given by the tutors or tutors fail in using the right approach in their delivery of instructions. However, looking at the margin of students difficulty areas, findings and personal interviews conducted, it is obvious that majority of the tutors resort to source and share information approach rather than the guiding principle. It also clearly indicated the ignorance of tutors about learning being active process of constructing rather than passively acquiring knowledge, and instruction being the process of supporting the knowledge constructed by the learners rather than the mere communication of knowledge. In this case the latter's support system is a mere communication devoid of technological facilities that enhance music education. There is therefore the need for harmonization of tutors' knowledge, approach to delivery involving computer technology and students' perception, reception and assimilation.

\section{Tutors' response regarding introduction of music technology into the current curriculum}

Table 11 showed tutors' responses regarding introduction of music technology into the current curriculum. All selected tutors responded positively representing $100 \%$. In interview to find out as to why music tutors perceive introduction of music technology in to the current curriculum, the following were some of music tutors' responses: i) Music tutors explained that introduction of music technology will enhance and simplify concepts to students. One tutor said "it will break abstract teaching"

ii) Tutors indicate that it will be very helpful to both tutors and students but accessibility to computers will be a great challenge. One tutor said "it helps to solve modern challenges but must be based on the technological readiness of the tutor"

iii) Tutors suggest that computer technology is indispensable. One said "it is very important in all aspect of Music Education.

\section{Students' response regarding introduction of music technology into the current curriculum}

Table 12 indicated students' response in regards to the introduction of music technology into the current curriculum. $85 \%$ of the sampled students were optimistic while $15 \%$ were pessimistic. Students gave various reasons why computer technology should be integrated in the current curriculum as follow:

i) Students indicated that computer technology is necessary because students become abreast with the technological advancement of the day.

ii) Students pointed out that computer technology will help improve upon the quality of educational delivery.

iii) One student has this to say "it is very nice and good to use computer to teach because it helps in composition"

iv) Students were of the view that computer technology will make music easy to learn and help students to master the subject practically as well. One student said "it aids teaching and learning of the subject and gives more understanding to the subject".

In all, both the students and tutors agreed that computer technology is indispensable in the present age of music education.

\section{Students' usage of computer technology in music education}

The study exposed the fact that apart from the purposes of communication as everyday routine, music students' frequent use of computer technology facilities falls below average. This presupposes students' lack of interest in the use of technology facilities in and outside the classroom, lack of the awareness of the roles of computer technology in music education and lack of competent computer technological skills necessary for music instruction and learning or education. In this regard, careful analysis of the results of the study revealed that tutors resorted to using traditional methods of educational instructions rather than the modern and more appropriate and technologically convenience means. This practice becomes one of the factors eliciting lack of motivation for students who fail to choose music as an elective subject. In other words it should be recorded that lack of students' motivation for the subject music comes as a result of three factors namely: lack of tutor motivation, abstract delivery of music lessons by music tutors and students perception of the subject music as difficult.

\section{Instructional prospects for use of computer technology in music education}

Research Question four (4) looked at curriculum areas/topics where students and tutors experienced difficulty. The study revealed that tutors' mostly experienced difficulty in practical topics. The least used computer applications by music tutors were the Computer Assisted Instruction and the presentational applications which are dearer to the heart of music education and music technology instructions. It was found that both tutors and students held a strong advocacy for the introduction of computer music technology into the current music curriculum to enhance music teaching in areas like Aurals, Composition and Piano skills teaching which they find difficult. This means that such music topics are a challenge hence finding new ways of incorporating the existing and newly developed technology into the teaching of music may open up new methods for the learning and teaching of music. In the study, one of major findings was that there seemed to be no specific planned formal training in computer and music 
software for music tutors as part of the courses of study during their formal training period. If there was any at all, it seemed to have little or no impact on the performance of music tutors. For now, any idea/training about the usage of music software came as a result of music tutor's self-initiated efforts outside the regular studies. Most often, these self-initiated technological programmes or skills and training acquired by music tutors were not purposively directed towards enhancing technologically oriented music education.

\section{Conclusion}

The availability of accessible computers in the colleges of education is a good indicator for embracing technologically enhanced environment for teaching music. Nevertheless, this perception cannot single-handedly make easy the implementation advocacy for the usage of computer technology in music education if colleges lack other technological facilities such as electronic keyboards, musical digital recorders and music software for teaching. In acknowledging the significant role played by computer technology in music instruction, the consideration for music tutors' competence in colleges of education must go beyond the acceptance of only academic qualifications. However, the process of selecting a college music tutor needs a critical analysis of the potential tutor's competency in handling computer and other music technologies in the classroom. Contrary to this, there is a tendency of varied individual tutor's awareness on the importance and use of computer and music technology facilities thereby defeating the full realization of the significant roles played by computer technology in music instruction.

One important factor that aids diffusion innovation process is motivation. The purpose of the deployment of computer technology to colleges of education cannot be achieved if they are not effectively used by students. From the study, it is concluded that there are two main factors that contribute to student's failure to use computer technology which the researcher referred to as inter and extra factors. The inter factor indicates the satisfaction individual student derives from appreciating the technology (being aware of its capabilities and flexibility) at his or her first encounter that leads to repeated action. The second factor, extra, leads to motivation derived by a student as a result of display of competence from a mate or a tutor. In many cases, the tutor being the center of focus provides the motivation during the delivery of lesson through the use of computer technology. These two factors are inseparable of each other. Where one of these factors is downplayed, it results in a learning difficulty referred to by the researcher as technology practice difficulty. This is evident in computer technology that is not user-friendly and abstract lesson delivery lacking the use of computer technology.

Finally, the prospect of computer technology use in music education is paramount. In enhancing effective computer technology music education for colleges of education in Ghana in the $21^{\text {st }}$ Century, Computer Assisted Instructions are indispensable. It is impossible to achieve the full potential of the use of computer technology in music education without integrating computer music technology in the course of study for colleges. Rogers (1962), defines the Theory of Diffusion Innovation as the process by which an innovation is adopted and gains acceptance by members of a certain community. According to Rogers (2003), he states "full use of an innovation as the best course of action available" and rejection is a decision "not to adopt an innovation" (p. 177). In his assertion, it was indicated that innovation itself, how information about the innovation is communicated (channel of communication), time and nature of social system (the institution) into which the innovation is being introduced are factors that interplay to influence the diffusion of an innovation.

The current study in line with its findings agreed with Rogers that lack of competence in the part of the college music tutors to use computer technology in teaching music was greatly influence by the process of imitative integration; the time these initiatives were introduced to colleges and how effective the knowledge of these technologies were communicated to both tutors and students. Lack of interest as shown by the in the part of tutors makes it very difficult for the full adoption of computer technology in teaching music. The introduction of computer technology to colleges of education must be well explained to users (tutors and students) and considering the appropriateness of the technology to the sector (music education) that is to use it. The Diffusion Innovation theory rightly complement to this study to call for proper assessment and analysis of colleges of education's computer technology needs for effective use of computer technology in teaching music.

\section{Recommendations}

From the findings of the study, it is obvious that the Colleges of Education cannot make a head way in the modern trends of music education delivery if certain measures are not taken. To make the implementation advocacy easy for the usage of technology in music education, there is the need for assessment, focus and redirection of priorities. It is long overdue for public sector to assess and identify the strengths and weakness of all ICT initiatives for colleges of education for further improvement. From the study, the public sector led ICT initiatives were not purposive to the direct needs of different subject orientations; instead individual tutors must be innovative enough in applying them to their fields of endeavour. It is therefore recommended that government's technology initiatives for Colleges of Education be re-designed to provide necessary subject oriented computer hardware and software, and where necessary, as alternative, give right atmosphere to colleges to acquire these facilities at cheaper prices 
to augment the shortfall in government's subventions. This would help achieve a uniform distribution of computer technologies across colleges. Subsequent initiatives must be concerned with the specific goals of the colleges, subject focus alongside the training requirements for teacher trainees.

In the study, it is revealed that for the success of computer technology in the music education, there must be interest development. Individual tutors and students as well have to whip up interest in availing themselves and making every effort to see technology as an effective tool for service delivery. In order to supplement and cater for the current backlog of knowledge needed for music education, as revealed by the study, music tutors in the college system should be taken through adequate seminars in the form of workshops, job-related refresher trainings in the knowledge of skills related to application of newly developed technologies in music education. It is hoped that if tutors would use appropriate approaches and principles and achieve the best of accepted standards, students would be motivated to apply same for better results. Organizations whose goals are to promote music education such as Association of Music Educators of Colleges of Education in Ghana should be encouraged and supported, as such give tutors opportunity for developing and sharing resources, besides providing professional experience. Tutors should develop habit of creating technology environment for student to have frequent hands on practices.

The study showed that the training of music tutors must be subjected to critical assessment. As we think about refresher training for those tutors on the job, the formal training of music tutors should involve taking pre-requisite courses in Information and Communication Technology as a preparatory lesson for effective integration of technology and specifically technology oriented music education courses; for no individual or an organization can function well in the present technological dispensation without relevant knowledge in ICT. According to the research, very few tutors who have little idea about the use of computer technology do not have the confidence to apply their knowledge to the profession. They lack personal motivation hence find it impossible integrating technology in music education. Lack of confidence may come as a result of lack of frequent use of technological facilities. It is therefore recommended that distributions of computer technology in the colleges should embrace departmental focus instead of the centralized system (laboratory system) to enhance easy access and use by the tutors. Finally, as advocated by both tutors and students, it is recommended that computer music technology be introduced into the current music curriculum in the colleges of education to enhance music teaching in areas like Aurals, Composition and Piano skills teaching which they find difficult.

\section{Suggestion for further studies}

The study was a survey and limited to the Colleges of Education in the Volta Region and addressed one area in education. It is therefore suggested that in-depth study could be done into how the use of technology enhances academic improvement in music among colleges of education as a whole. Again, there could be a comparative study of two or more schools in relation to academic performance in music and usage of computer technologies by teachers during instructional hours. It is hoped that, this research will spread across all other educational institutions that benefit from ICT integration process and the teaching of music as a subject to prepare us meet global digital quest.

Acknowledgements: Herbert Adom-Adjei, Bridgit Adom-Adjei, Missper Mawusi

\section{References}

Akuno, E. A. \& Digolo B. (2000). Computer as A strategy for Enhancing Music Education in Kenyan Institutions of Higher Learning. A paper presented at the National Conference on Higher Education for Human Development in Kenya, Kenyatta University, 17th - 20th April

Allen, J. (2004) Discrimination of modes of action of antifungal substances by use of metabolic footprinting. Appl Environ Microbiol 70(10), 6157-65

Amedahe, F. K. (2002). Fundamentals of educational research methods. Mimeograph. Cape Coast, University of Cape Coast Press.

Anderson, J. R., Reder, L. M., \& Simon, H. A. (1996). Situated learning and education. Educational Researcher, 25(4), 5-11.

Bajjaly, S.T., 1998. Strategic information systems planning in the public sector. Am. Rev. Public Admin., 28, 7585.

Barron, A. (1998). Designing Web-based training. British Journal of Educational Technology, 29(4), 355-371.

Bauer, W. I., Reese, S. \& McAllister, P. A.(2003). Transforming music teaching via technology: The role of professional development, Journal of Research in Music Education, Winter 51(4), 289-301.

Berge, Z. (1998). Guiding principles in Web-based instructional design. Education Media International, 35(2), 72- 76.

Black, J. B., \& McClintock, R. O. (1995). An interpretation construction approach to constructivist design. Retrieved May 6, 2017, from http://www.ilt.columbia.edu/publications/papers/ICON_print.html (http://en.unesco.org/themes/ict-education),

Brennan, S. E., \& Lockridge, C. B. (2006). Computer-mediated communication: A cognitive science approach. 
ELL2, Encyclopedia of Language and Linguistics, , pp. 775-780.

Brush, T., \& Saye, J. (2000). Implementation and evaluation of a student- centered learning unit: A case study. Educational Technology Research \& Development, 48(3), 79-100

Carlson, S., and C.T. Gadio. (2002). Teacher professional development in the use of technology. In W.D. Haddad and A. Draxler (Eds), Technologies for education: Potentials, parameters, and prospects. Paris and Washington, DC: UNESCO and the Academy for Educational Development. • Tinio, V. ICT in Education.

Clark, C., \& Munn, R. E.(1986. ). Sustainable development of the biosphere, Cambridge University Press. Quarterly Journal of the Royal Meteorological Society, 114, 480.

Clark, C. M., \& Peterson, P. L. (1986). Teachers' thought processes, in:M. C. Witt rock (Ed.)Handbook of research on teaching (New York, Macmillan).

Creswell, J. W. (2003). Research design: Qualitative, quantitative, and mixed methods approaches ( $2^{\text {nd }}$ ed). Thousand Oaks, C.A: Sage.

Duffy, T. M. \& Cunningham, D. J. (1996). Constructivism: Implications for the design and delivery of instruction. In D. H. Jonassen (Ed.), Educational communications and technology (pp. 170-199). New York: Simon \& Schuster Macmillan

Fang, Z. (1996). A review of research on teacher beliefs and practices. Educational Research, 38(1), 47-65

Flolu, J. E. (1994). Re-Tuning Music Education in Ghana: A Study of Cultural Influences and Musical Developments, and of the Dilemma Confronting Ghanaian School Music Teacher. University of York: Department of Music, pp. 57

Gardner, H. (1991). Frames of mind. New York: Basic Books.

Government of Ghana (2000). Ghana Education Trust Fund Act, (p. 1-8)

Government of Ghana (2005). Government of Ghana Ministerial ICT Policy Statement: Accra: NBS Multimedia Government of Ghana (2015). Ghana ICT in Education Policy, 6-37

Jonassen, D. \& Reeves, T. (1996). Learning with technology: Using computers as cognitive tools. In D. Jonassen (Ed.), Handbook of Research Educational on Educational Communications and Technology, 693-719. New York: Macmillan.

Jonassen, D. H. (1991). Evaluating constructive learning: Educational Technology, 31 (9), pp. 28-33. 154

Jonassen, D. H., Peck, K. L., and Wilson, B. G. (1999). Learning with technology: A constructivist perspective. New York: Prentice Hall.

Lave, J. (1988). Cognition in practice: Mind, mathematics, and culture in everyday life. Cambridge, England: Cambridge University Press

Lebow, D. (1993). Constructivist values for instructional systems design: Five principles toward a new mindset. Educational Technology, Research and Development, 41(3), 4-16.

Lehman,P.R. (2001). The class of 2001: Coping with the computer bandwagon. Reston, VA: a paper presented at the Music Educators National Conference.

Malachi D. (2007), A survey of computer usage in Secondary School. Nairobi Kenya; Unpublished thesis

Mangesi, K, (2007), ICT in Education in Ghana; Survey of ICT and Education in Africa: Ghana Country Report, $1-9$

Marcellino, R. (1996). Technology and Music Literacy. Journal of the Australian Music Centre, 14 (47), 45-48

Medlin, B.D. (2001). The factors that may influence a faculty member's decision to adopt electronic technologies in instruction (Doctoral dissertation, Virginia Polytechnic Institute and State University, 2001). ProQuest Digital Dissertations. (UMI No. AAT 3095210).

Mereku C.W.K. (1999). Challenges in implementing the new music and dance syllabuses for primary and junior secondary schools in Ghana. Paper Presented at the Workshop on Teaching of African Music and Dance: University of Ghana, Legon: International Centre of African Music and Dance (ICAMD). 15, $-17^{\text {th }}$ December, 1999.

Mfum-Mensah, O. (2003). Computers in Ghanaian Secondary Schools: Where Does Equality Come In?. Unpublished Ph.D. dissertation. University of Toronto.

Monahan, T. (2004). Technology policy as a stealth agent of global change: Globalisation. Societies and Education, $2,355-376$

Muro, D. (1996). On behalf of Humanity in the technological edge. The World \& I, 301-313.

Myhre, O. R. (1998). I think this will keep them busy: computers in a teacher's

thought and practice. Journal of Technology and Teacher Education, 6(2/3), 103.

Nketia, J. H. (1966). Music Education in African Schools: A Review of the Position in Ghana. in International Seminar on Teacher Education in Music. Ann Arbor: Univ.of Michigan, (pp. 231-243)

Norris, D., McQueen, J. M., \& Cutler, A. (2003). “Perceptual learning in speech,” Cognitive. Psychology, 47, 204238.

Nyamful, A.Y. (2016). The Current State of Music Education in Ghana: A call for integration of Information and Communication Technology (ICT). Journal of Arts and Humanities, 5, (4), 62-68. Retried (October 4, 2017) 
from http://www.theartsjournal.org/index.php/site/article/view/716. doi:http://dx.doi.org/10.18533/journal.v5i4.716.

Ohene-Okantah, M. (1997). Music in Ghanaian Education: In Search of a National Philosophy. $21^{\text {st }}$ Annual National Conference of Ghana Music Teachers' Association, Akropong-Akwapim, 25 ${ }^{\text {th }}-28^{\text {th }}$ August, 1997.
Retrieved
(October
1 ,
2017),
from
www.scientificafrican.org/sciafr/publications/musiceducator/no10/.../at download (pp. 3-4)

Okonkwo, V. N. (2008). ICT and Music Education: The New Path Music Enthusiast in the Nigerian Society. Journal of Women in Colleges of Education (JOWICE) 10 (1), 36-38.

Oliver, R. (2000). Creating Meaningful Contexts for Learning in Web-based Settings. Proceedings of Open Learning 2000, 53-62. Brisbane: Learning Network, Queensland

Oliver, R. \& Towers, S. (2000). Benchmarking ICT literacy in tertiary learning settings. In R. Sims, M. O'Reilly \& S. Sawkins (Eds). Learning to choose: Choosing to learn. Proceedings of the 17th Annual ASCILITE Conference, 381-390. Lismore, NSW: Southern Cross University Press.

Ottesen, E. (2006). Learning to teach with technology: authoring practised identities. Technology. Pedagogy and Education, 15(3), 275-290. doi:10.1080/14759390600923568

Pajares, M. (1992). Teacher's beliefs and educational research: cleaning up a messy construct. Review of Educational Research, 62(3), 307-332

Parisot, A.H. (1997). Distance education as a catalyst for changing teaching in the community college: Implications for institutional policy. New Directions for Community Colleges, 99, 5-13.

Peters, G. D. (2000). Music Software and Emerging Technology. Music educators Journal, 79(3), 22-25.

United Nations (2003). Population, Education and Development: The Concise Report, New York.

Reeves, T.C. \& Janassen, D.H. (1996). Learning With Technology: Using Computers As Cognitive Tools. AECT: 1800 North Stonelake Drive, Suite 2 Bloomington, IN 47404

Reiser, R. A. (2002). Instructional planning: A guide for teachers (2nd Ed.), Boston: Allyn \& Bacon.

Republic of Ghana (2003). The Ghana ICT for accelerated development (ICT4AD) policy. Accra, Ghana: Graphic Communications Group Limited. Retrieved (February 15, 2008) from http://www.moc.gov.gh/moc/PDFs/Ghana_ICT4AD_Policy.pdf

Razavieh, A. (1990). Introduction to research in education (4th ed.). Fort Worth: Harcourt Brace Jovanovich.

Richards, R. T. (1998). Infusing technology and literacy into the undergraduate teacher education curriculum through the us of electronic portfolios. T.H.E. Journal, 25(9), 46-50.

Rogers, E.M. (1962). Diffusion of Innovations. New York; Free Press.

Rogers, E.M. (2003). Diffusion of innovations (5th ed.). New York: Free Press.

Rudolph,T. E. (2004) (Teaching Music with Technology (2 $2^{\text {nd }}$ ed), GIA Publications, Inc. Chicago

Sevan, N. (2016). Music Software in the Technology Integrated Music Education. Bartin University, Faculty of Education, Department of Fine Arts, Turkey. Turkish Online Journal of Educational Technology (2016). 15(2), 78, Retrieved (October 2, 2017) from sevannart@bartin. edu.tr

Schwarz, N. (1999). Reports of subjective well-being: Judgement process and their methodological implications. In Kalneman, D., Diener, \& Schwarz (Eds.), Well-being: The foundations of hedomic psychology (pp. 61-84). New York: Russell Sage Foundation.

Soloway, E. \& Pryor, A. (1996). The next generation in human-computer interaction. Communications of the ACM, 39(4), 6-18.

Surry, D., \& Farquhar, J. (1994). Adoption analysis: An additional tool for instructional developers. Education and Training Technology International, 31(1), 19-23.

Taylor, R. (1980). The Computer in the School: Tutor, Tool, Tutee. New York, NY: Teachers College Press.

UNESCO. (2001). Teacher Education through Distance Learning: Technology - Curriculum - Cost - Evaluation Paris: UNESCO

United Nations (2003). Report on Population, Education and Development. United Nations Publication, New York. Yildirim, S. (2007). Current Utilization of ICT in Turkish Basic Education Schools: A Review of Teacher's ICT Use and Barriers to Integration. International Journal of Instructional Media, 34, (2), 171-86

Zeichner, K. M., Tabachnick, B. R. \& Densmore, K. (1987). Individual instructional and cultural influences on the development of teachers' craft knowledge, in: J. Calderhead (Ed.). Exploring teachers' thinking (Eastbourne, Cassell), 1-2 